\title{
Ownership, Control and Market Liquidity
}

Edith Ginglinger: University Paris Dauphine, Paris, France

Jacques Hamon: University Paris Dauphine, Paris, France

CONTACT: Edith Ginglinger, University Paris Dauphine, Place du marechal de Lattre, 75775

Paris, France.

Email: edith.ginglinger@dauphine.fr

\section{Ownership, control and market liquidity}

June 2007

Key words: ownership, ultimate control, pyramids, voting rights, liquidity, bid-ask spread

JEL classification: G32, G34, G14

\section{Abstract}

We examine how ownership concentration and the separation of ownership and control affect market liquidity in France. We find that firms with a large insider blockholder exhibit significantly lower liquidity. Different methods of concentrating control affect liquidity in different ways. Pyramid structures negatively affect liquidity for all pyramiding firms. Double voting right shares, a French specific means of control enhancement rewarding long-term shareholders, lead to increased liquidity for outside investors of small, familyfirms, by reducing the probability of informed trading. 


\section{Introduction}

Whether corporate governance affects market liquidity is a matter of much debate. Market liquidity is a component of the transaction costs born by investors. Liquidity is also essential for arbitrageurs to keep share prices in equilibrium. Therefore, investors prefer to invest in liquid stock markets. The objective of this paper is to examine the effect of ownership structures and corporate governance on market liquidity. We do so within the French institutional setting, which is characterized by firms with concentrated ownership. We pose three questions. First, to what extent does ownership concentration affect liquidity? Second, is separation between control rights and cash-flow rights associated with lower liquidity? Third, do the devices used to enhance control (pyramid schemes, double voting right shares, voting caps...) have similar effects on liquidity?

It is generally believed that dispersed ownership leads to increased market liquidity (see for example Bolton and Von Tadden, 1998). There are two potential explanations for the association between ownership structure and market liquidity. First, the trading or free-float hypothesis posits that the liquidity of a stock is increasing in the market capitalization of a firm. Average transactions costs depend on the number of shareholders participating in trade. When a firm's ownership is concentrated, the free float is limited, there are fewer trade, and therefore the liquidity is decreased (Demsetz, 1968). Moreover, ownership structure may affect liquidity through the production of information. According to Holmström and Tirole (1993), concentrated ownership reduces the benefit of monitoring the firm by stock market participants, thereby reducing the amount of public information available about the firm. The number of market participants willing to invest in information acquisition in a firm is larger, the larger the anticipated gains from trade, which are directly related to the stock's free float.

The second explanation is the adverse selection hypothesis. Concentrated ownership is potentially costly, because blockholders may have private information about firm value. In response to a higher probability of informed trading, liquidity providers may widen spreads. A large body of theoretical work describes how markets react to the presence of informed traders (see for example Glosten and Milgrom, 1985). In practice, however, it is difficult to know which participants are informed and which are uninformed. According to the SEC, managers and controlling shareholders at the 10\% threshold are classified as insiders. Empirical studies frequently assume institutional investors to be informed. They have not access to private information, but may exploit economies of scale in information acquisition. Most previous ownership-liquidity studies have taken into account institutional ownership. ${ }^{1}$ 
However, as institutions prefer more liquid stocks, empirical investigations have to examine endogeneity between liquidity and institutional holdings. Rubin (2007) documents a high negative correlation between insiders' blockholdings and institutional holdings, confirming that institutions are more willing to invest in firms with less concentrated insider ownership. Following the SEC definition of insiders, our study concentrates on manager and controlling shareholder ownership. Our choice is further motivated by the fact that insiders' blockholdings are on average very large in France (more than 50\% according to our data) compared to $5.10 \%$ in the US (Rubin, 2007).

Beyond the impact of concentrated ownership on liquidity, we also investigate the impact of separation between ultimate control and ownership on adverse selection and therefore on liquidity. Our analysis has two components. First, even if some degree of ownership concentration improves control of management, a larger deviation of control from ownership may be associated with a severe agency problem between controlling and minority shareholders. The incentives to extract private benefits are greater when not restrained by the controlling shareholder's own cash flow stake. Furthermore, the ultimate owner may choose a poor disclosure policy, worsening the information asymmetry problem, to trade on his private information. When the private benefits become a substantial share of the firm's value, minority shareholders may refuse to buy shares, leading to poorer market liquidity. Beny (2004) reports that weaker inside trading regimes have, at least, less liquid equity markets. Brockman and Chung (2003) show that Hong Kong based equities, operating in a good investor protection environment, exhibit narrower spreads than their low protected Chinabased counterparts. Dahlquist, Pinkowitz, Stulz, and Williamson (2003) find differences in investor protection and corporate governance may help understand the U.S. investors' home bias. They report that the home bias is significantly smaller, but does not disappear, when controlling shareholders are taken into account. For example, the French market represents $2.96 \%$ of the world portfolio, $2.34 \%$ of the world float portfolio, but $0.65 \%$ of the U.S. investors' portfolio. Keeping other factors constant, divergence of control from ownership should therefore result in a wider bid-ask spread and lower stock liquidity. More directly, using a Canadian sample of publicly-traded firms, Attig, Fong, Gadhoum and Lang (2006) find evidence that the bid-ask spread widens with the deviation between ultimate control and ownership.

Second, we investigate the impact on liquidity of how the firm chooses to enhance control. The two main ways to achieve separation of voting rights from cash flow rights are pyramiding and using different classes of shares that provide different voting rights for given 
cash flow rights. A pyramid structure allows indirect control of a firm by a chain of ownership relations using only a small cash flow stake. Through the use of different classes of shares, a controlling shareholder can achieve separation by directly owning the firm and selling shares with inferior or no voting rights. Both devices allow separation. However, with dual-class shares or equivalent mechanisms, the insiders hold superior voting right shares, and therefore, may not trade on inferior voting right shares. As a consequence, the probability for market participants to trade against insiders may be reduced, and the liquidity increased.

Our objective is to test the trading hypothesis and the adverse selection hypothesis, using a French sample of 1550 firm-year observations. The average French firm has concentrated ownership. French firms only rarely use dual-class shares. However, control is often enhanced via pyramid structures and double voting right shares, a specific French device that allows double voting rights for registered shares held for more than 2 to 4 years, depending on the firm's charter. Double voting rights are a means of rewarding long-term shareholders. The double voting right share loses its additional voting right when it is sold, and is negotiated like a single voting right share. The shareholders have to choose between the double voting rights and the liquidity of their shares.

First, we test for an association between float and several liquidity measures. In accordance with the trading hypothesis, we find a positive relation between float and liquidity. Second, we examine the impact of ultimate control rights. We find spreads increase and depths decrease in ultimate control. Third, we report that deviation of ultimate control from ownership has a positive impact on spreads. Fourth, contrary to the results in Attig et al (2006), we find that the impact on spreads of deviation of control from ownership depends on the control enhancing device used by the firm. Pyramid structures have a positive impact on spreads as well as on the adverse selection component of the spread, whereas double voting right shares decrease spreads. Our results are consistent with the adverse selection hypothesis. When the separation device used by the firm prevents insiders to trade on their private information, which is the case for double voting rights, it reduces information asymmetries and therefore the bid-ask spread. On the contrary, pyramid structures permit large divergence between control and ownership and do not prevent insiders to trade. They enhance information asymmetries and decrease liquidity. Whereas the negative impact of pyramids on liquidity prevails for all pyramiding firms, the positive effect of double voting rights is limited to small family-firms. 
The remainder of the paper is organized as follows. In Section 2, we describe the institutional and legal environment of the French firms' ownership and our hypotheses. In Section 3, we describe data. In Section 4, liquidity measures and methodology are developed. In Section 5, empirical results are reported. Section 6 summarizes and provides conclusions.

\section{Ownership structure on the French market and market liquidity}

\section{II.1. The French institutional and legal environment}

In France, as in most Western European countries, ownership tends to be concentrated. Faccio and Lang (2002) show that $36.93 \%$ of European firms are widely held, whereas in France this percentage decreases to $14 \%$. $44.29 \%$ of European firms are controlled by a single family, versus $64.82 \%$ in France. Further, this concentration of ownership in France differs appreciably from that prevailing in the US. On average, Dennis and Weston (2001) report insiders own $9.79 \%$ of the U.S. firm's stock while institutions altogether own $31.06 \%$ of the firm's stock. In Heflin and Shaw (2000), the mean total block ownership is $12.3 \%$ of shares outstanding.

Central to the question of governance is the way shareholder general meetings operate. Under French law, there are two types of general meetings. Decisions by ordinary meetings, which approve the accounts, appoint and dismiss directors, and decide bond issues, require a majority of $50 \%$ of voting rights to be adopted. Decisions by extraordinary meetings pertain to all decisions amending the charter and issuing shares and require a two-thirds majority of voting rights. Therefore, three thresholds appear particularly important: the threshold of $33.33 \%$ (blocking minority), a threshold of 50\% and a threshold of two thirds, which confers a super majority. However, in line with Faccio and Lang (2002) and earlier studies, we assume that 20 percent of the voting shares suffice to ensure control. If no shareholder exceeds the $20 \%$ threshold, then the firm is said to be "widely held", because in this case no one can unilaterally influence decisions without facing the opposition of other stockholders. Following the literature (Faccio and Lang, 2002), we take pyramiding into account to determine ultimate control rights. Firm A is said to be controlled through "pyramiding" if it has an ultimate owner, who controls B indirectly through another firm that it does not wholly control. 
Apart from pyramids, the most common device to enhance control rights in France are double voting right shares. The firm's charter can authorise double voting rights for registered shares that have been held for more than $\mathrm{x}$ years (where $\mathrm{x}$ is between 2 and 4 years). In contrast to dual-class shares, the voting right is attached to the shareholder. If he decides to sell his share, the buyer will acquire a share with only one voting right. Double voting shares and single voting shares trade at the same price, unlike dual class shares. Typically, controlling shareholders own double vote shares while most minority shareholders own single vote shares. The double voting share structure has not been taken into account in previous studies examining the case of France (for instance, Faccio and Lang, 2002).

Dual class shares were introduced in France in 1983 but are relatively rarely used. They are restricted to shares with no voting rights.

In addition to different per share votes, the charter may also include voting caps, which limit voting rights in general shareholders' meetings to $\mathrm{x} \%$ or a certain percentage of votes cast at the meeting. This means a shareholder can only use a certain percentage of his voting rights, and will only be able to use them all if he owns $2 / 3$ of the capital.

Finally, some French companies are limited partnership firm. They have partners with unlimited liability who manage the firm, in addition to other shareholders. As the active partners' shares are non-transferable, and the charter makes removal of the managing partner practically impossible, use of this form of legal entity precludes hostile takeovers.

\section{II.2. Hypotheses}

We examine two main hypotheses on the relationship between ownership structure and market liquidity.

\section{The free-float hypothesis}

Ownership concentration leads to a dissociation between market capitalization and free float. Market capitalisation measures all shares of the firm, even those which may never be traded on the secondary market. In view of the concentrated ownership structures in the EU, free float is a better measure of the size of the market for the firm's shares. Indeed, in the presence of a large shareholder, only the shares included in the free float are likely to be 
traded. In continental European countries, the difference between capitalisation and free float is larger than in the UK or the US (see for example Dahlquist, Pinkowitz, Stulz, and Williamson, 2003). A large shareholder controlling a listed company takes into account private control benefits and therefore trades differently than small atomistic shareholders. Therefore, when a firm's ownership is concentrated, the availability of shares is limited, there are fewer shareholders who can participate in the trading of the stock and the frequency of trades is reduced. A small float discourages the acquisition and the production of information. On the one hand the cost of acquisition of information probably increases and on the other hand the importance of transaction costs prevents the use of this information to generate profits. Therefore, the liquidity is decreased.

\section{The adverse selection hypothesis}

First, if large shareholders are more likely to be informed, their presence should increase the adverse selection discount associated with the trading of the stock, which implies a reduced liquidity. However, previous empirical studies, mainly conducted on US firms, lead to ambiguous results, partly because they do not distinguish between insider and institutional blockholdings. Heflin and Shaw (2000) report a positive association between spreads and block ownership (including insiders and institutional blocks). Sarin, Shastri and Shastri (2000) find that the spread is positively related to institutional ownership. Modelling the determinants of both ownership structure and spreads as a system of simultaneous equations, Dennis and Weston (2001) report that the spread is negatively related to both insider and institutional ownership, whereas Kini and Mian (1995) find no support for a significant relationship between spreads and blockholdings. Rubin (2007) reports that total institutional holdings as well as insiders' holdings have a negative effect on spreads, whereas institutional blockholdings have the opposite effect.

Evidence on the ownership-liquidity relation is rare outside the U.S. Comerton-Forde and Rydge (2006) document that in Australia, director holdings of less than ten percent of issued capital enhance liquidity, whereas director holdings greater than ten percent reduce liquidity. Institutional ownership concentration has no impact on spreads. However, their database excludes issuer registered shareholdings, which represent about $50 \%$ of the ownership. They therefore exclude a large part of the insiders' holdings. Naes (2005), for 
Norway, finds that block ownership leads to increased spreads but has no effect on depth. Institutional blocks have no impact on liquidity.

In our study, we concentrate on controlling blockholders and examine their impact on liquidity. Therefore, we do not take into account institutional investors, except if they control the firm. We suppose that controlling owners are better informed than other investors and that bid-ask spreads are larger and depth is lower to reflect the high probability of informed trade.

Second, we examine the impact of divergence between control and ownership on liquidity. Following La Porta et al. (2000), recent research demonstrates the importance of an economy's legal system on the quality of investor protection and the development and the liquidity of the financial markets. Several studies analyze the relation between investor protection and firm performance. ${ }^{2}$ However, few papers examine the impact of investor protection on liquidity. Most papers examining the impact of ownership on liquidity are in a "one-share-one-vote" setting. However the separation of control and cash-flows rights can have several effects on market liquidity. First, control can generate private benefits for controlling shareholders. ${ }^{3}$ In the presence of large private benefits, outside investors may not buy the stock, reducing the market liquidity. The ultimate owner may adopt a poor disclosure policy, to be able to trade on his private information. On the other hand, if a shareholder wishes to keep the control of a company, he will do it anyway. If he can use devices to enhance control, he will be able to hold a lower fraction of the shares to ensure control and float will therefore be more important, which has a positive impact on liquidity (see Becht, 1999).

Empirical evidence on these effects is limited. According to Bhide (1993), because of this information asymmetry, the spreads of closely-held firms are higher. Beny (2004) reports that weaker insider trading regimes have, at least, less liquid equity markets. Brockman and Chung (2003) focus on the link between investor protection and firm liquidity. The Hong Kong Stock Exchange lists two types of companies. Blue chip stocks operate in a good investor protection environment (Hong Kong) while the red chip stocks operate in the low protection Chinese environment. The results show that Hong Kong based equities exhibit narrower spreads and thicker depths than their China-based counterparts. To our knowledge, Attig, Fong, Gadhoum and Lang (2006) are the first to examine the direct relation between stock liquidity and ultimate ownership. They find that a larger separation between ultimate control and ownership results in more severe information asymmetry and wider bid-ask spreads. 
Third, we examine if the method shareholders use to separate ownership and control affects liquidity. Pyramids are typically opaque and have a negative impact on liquidity. On the other hand, double voting right shares generate a transparent separation between cashflows rights and voting. Insofar as the insiders hold double voting right shares, they will lose them when selling their shares. Thus, insiders will probably avoid trading their shares, to keep their double voting right. One can argue that double voting rights prevent insiders to sell, but not to buy shares. However, insiders are more likely to sell in order to liquidate their holdings, unlike institutional investors. Therefore in the market, all things being equal, the probability for market participants to face insiders is lower in the presence of double voting right shares. The double voting right makes it possible to keep them away. Boehmer, Sanger and Varshney (2004) present this argument for dual-class shares. They show that the spread of low voting right dual class shares is smaller because insiders hold shares with high voting rights. An outside investor in low voting right shares is therefore less likely to be in the presence of an informed insider.

We can thus sum up our hypotheses:

H1. The liquidity of a closely-held firm stock is ceteris paribus lower because the float is smaller.

H2. The liquidity of a closely-held firm is lower because of a higher probability of informed trading, as blockholders may have access to private information.

H3. The impact of the separation of control from ownership depends on the device used by the firm. Separation through pyramiding should reduce liquidity whereas using double voting right shares, which deter informed trade, should increase liquidity.

III. Data

\section{Euronext data}

We use the Euronext intraday database. Our dataset contains a time-stamped record of all transactions and orders submitted to the market from July 1998 to July 2003 for all French listed firms (918). These data include transaction prices, volumes, and the best limits of the order book (bid and ask prices, and bid and ask size), as well as market capitalization. All data are stamped to the nearest second. 
Euronext Paris is an electronic limit order market. There are two main market models: continuous trading, for the more actively traded stocks, and a double auctions market for the less liquid stocks. A description can be found in Biais, Hillion, and Spatt (1999). A call auction determines the opening and closing price in the continuous market. Trading takes place continuously from 9:00 to $17.25{ }^{4}$ Traders mainly use limit orders and market orders. Deferred settlement is possible for a subset of the more liquid shares: this market segment is called the "service à réglement différé" or SRD. For all other shares, only cash trading is possible. All SRD stocks belong to the continuous market. The SRD market segment accounts for approximately $89 \%$ of the total market value of Euronext Paris, and $97 \%$ of the turnover. In several cases, we report results for subsamples by market (CAC40 index shares, nonCAC40 SRD shares, cash-only shares).

Euronext Paris offers substantial transparency. The five best bid/ask limits (price and quantity) in the order book are publicly released and members have access to all orders outstanding in the book, although the identity of the broker is not shown.

Traders can also submit iceberg orders (also referred to as hidden-size orders). For these orders, only specified tranches are successively entered in the order book, and disclosed to the market, with the current time stamp after full execution of the preceding tranche.

\section{Ownership and governance data}

There is no electronic database on French firm ownership, including relevant information on double voting rights and corporate governance characteristics. We manually collect this information from firm's annual reports for three years 1998, 2000 and 2002. The ownership structures are those available on the $31^{\text {st }}$ December of each year. Our sample includes all French listed firms, for which the annual reports are available. Table 1 reports characteristics for the 1550 firm-observations of our database and for subsamples by market.

\section{[Insert Table 1 here]}

These data confirm that French firms are closely-held. On average, the largest shareholder directly holds $46.42 \%$ of the capital and $51.99 \%$ of the voting rights. ${ }^{5}$ These percentages are smaller for the firms in the CAC40 (other SRD), for which the largest 
shareholder has $21.19 \%(39.11 \%)$ of the capital and $24.42 \%$ (44.84\%) of the voting rights and is larger for the firms on the cash-only market $(51.27 \%$ of the capital and $57.05 \%$ of the voting rights). The second largest shareholder holds on average $7.37 \%$ of the capital and $7.65 \%$ of the voting rights. The float, which corresponds to the percentage of the capital pertaining to shareholders not identified or holding less than $5 \%$ of the capital, amounts on average to $41.06 \%$ of the capital for the total sample. It is greater for the CAC40 firms (70.27\%) and lower for the cash-only firms (35.44\%). On average, the employees own $0.83 \%$ of the shares of their company, but this percentage amounts to $2.10 \%$ for the CAC40 companies. The firms hold on average $0.96 \%$ of their own shares $(1.87 \%$ for the CAC40 firms).

We also identified the ultimate controlling shareholders in the presence of pyramids, for a threshold of $20 \%$ of the voting rights, as in Faccio and Lang (2002). On average, the largest shareholder holds $43.64 \%$ of the capital and $50.99 \%$ of the voting rights.

We further take into account the identity of the shareholders. In the family category are management, families and non-listed companies. At the $20 \%$ threshold, $70.1 \%$ of the companies are controlled by a family, which hold on average $50.71 \%$ of the capital and $60.04 \%$ of the voting rights. Families control $29.4 \%$ of the CAC40 companies holding on average $37.12 \%$ of the capital), $51.9 \%$ of the other SRD firms ( $40.26 \%$ of the capital), and $79.8 \%$ of the cash-only firms (53.24\% of the capital). The French listed companies are thus largely controlled by families. Among the other controlling shareholders, 9.2\% are financial institutions, $4.8 \%$ widely-held companies, and 2.8\% the French State. 9.2\% of the CAC40 firms are ultimately controlled by the French State. For the total sample, only $13.1 \%$ of the firms are widely-held, but this proportion amounts to $47.9 \%$ for the CAC40 companies and is reduced to $7.8 \%$ for the cash-only firms.

We then examine the methods used by the French firms to ensure separation between control rights and ownership rights held by large shareholders (Table 2). Double voting rights are the most frequent device used by $68.3 \%$ of the firms, and for $52.2 \%$ of them it is the only enhancing device they use. Pyramids are used by $18.5 \%$ of the firms, voting caps by $2.3 \%$ of the firms, dual-class shares by $1.2 \%$ and the limited partnerships by $1.8 \%$.

CAC40 companies use the most the control-ownership separation mechanisms. In addition to double voting rights, used by $71.4 \%$ of them, $18.5 \%$ have voting caps, $24.4 \%$ pyramids, $4.2 \%$ dual-class shares, and 5\% limited partnerships. On the other hand, cash-only firms use mainly double voting shares, whereas $32.7 \%$ of other SRD firms are pyramids. 
The identity of controlling shareholders also seems to affect how firms separate ownership and control. Families typically use double voting rights; the other controlling shareholders (financial institution, State and another widely held firm) prefer pyramids.

[Insert Table 2 here]

\section{Liquidity measures and methodology}

We include in our study several liquidity measures, divided into trade-based measures and order-based measures. Trade-based measures include the number of trades and the turnover. Order-based measures include depths and effective relative bid-ask spreads. Depth at the opening is measured by the natural logarithm of the sum of the value in Euros of shares posted at the best limits first observed in the order book that trading day. We calculate the daily average relative effective spread, estimated using full day data records. The number of spreads over a trading day varies according to the number of transactions. The effective spread takes into account the possibility of a transaction within the spread, although in practice this is rare on the Paris exchange. ${ }^{6}$ The relative effective spread relates the spread to the midpoint of the spread ${ }^{7}$ :

$$
\begin{aligned}
& \text { Effective Relative Spread }=\frac{2 \times \mid \text { Trade Price }- \text { Midpoint } \mid}{\text { Midpoint }} \text {, where } \\
& \text { Midpoint }=\frac{\text { Ask Price }+ \text { Bid Price }}{2} .
\end{aligned}
$$

We average all liquidity variables over 12 months around the date of ownership structure for each year (6 months before and after).

To complement the univariate analysis, we use several regression models using ordinary least square (OLS) to explain liquidity. Liquidity is the dependent variable represented by either relative spread or depth. We log-transform the variable depth because of skewness in its distribution. The independent variables include a set of corporate governance variables and a set of control variables. We introduce three control variables. The cost components of the bid-ask spread fall into three categories: order-processing costs, inventoryholding costs, and adverse selection costs. Order-processing costs are largely fixed. The bid- 
ask spread should therefore decrease with trading volume. A market maker incurs inventoryholding costs when providing liquidity. In an order-driven market, limit order traders run the risk of non-execution, and inventory costs grow as volatility rises. The bid-ask spread should therefore increase with volatility. Adverse selection costs result from the risk of trading with individuals who possess private information. Several measures of adverse selection costs have been used in the literature. The bid-ask spread should increase with volatility (Copeland and Galai (1983)), while it should decrease with the size of the firm (market value of the shares) and the trading volume. ${ }^{8}$

In order to take into consideration the combined effect of the control variables suggested by previous studies of the determinants of the bid-ask spread, we introduce market capitalization and SRD, a dummy which equals to one when the share is traded on the deferred settlement market. We also introduce a volatility variable (average of the standard deviation of rates of return over one year around the date of ownership structure). Year dummies are also included.

Among the corporate governance variables set, we take into account: the percentage of capital owned by the controlling shareholder and the second largest shareholder, the identity of the controlling shareholder, the wedge between cash flow rights and control rights, and dummy variables capting the presence of pyramids, double voting rights, voting caps, dual class shares and limited partnership.

\section{Empirical results}

\section{Controlling shareholders and liquidity}

We expect liquidity measures to be lower for firms with controlling shareholders than for widely held firms. Table 3 presents univariate evidence of market characteristics and liquidity measures by subsamples of widely-held firms, family-controlled firms and nonfamily-controlled firms. The sample is further broken down by settlement method (cash-only and deferred settlement) and inclusion/non inclusion in the CAC40 index for deferred settlement companies.

[Insert Table 3 here] 
Widely-held firms are the firms largest in market value, are more volatile, are involved in the most transactions, and are more liquid than family-controlled firms and non-family controlled firms. Their average market capitalization is $€ 6,587.3$ million, compared to $€ 877$ million (€3,401 million) for family-firms (non-family-controlled firms). The widely-held firms' turnover and number of transactions are significantly larger than the other controlled firms ones, which, in turn, are larger than the family-firms turnover and number of transactions. The average relative spread is $1.46 \%$ for widely-held firms, $2.99 \%$ for familyfirms, and $1.99 \%$ for non-family controlled firms. The average depth is 68,400 euros for widely-held firms, 24,800 for family-firms, and 61,200 for non-family controlled firms. The breakdown of the sample shows that the size and the volatility of companies listed on the same market segment exhibit only limited differences according to the existence of a controlling shareholder. However, family-firms are still characterized by wider spreads and lower depth. In general, the descriptive statistics indicate that the widely-held companies are the largest and the most liquid firms, whereas family-controlled companies are the smallest and less liquid firms. Non-family controlled companies fall between these two profiles.

To complement the univariate analysis, we use several regression models. We estimate all regressions using ordinary least square (OLS). We use either the relative effective spread or the depth as the dependent variable. Table 4 reports the estimation results. Liquidity, regardless of measure, increases with market capitalization, and is greater for firms on the SRD market. Liquidity decreases as volatility increases. This result is consistent with previous findings on the determinants of the bid-ask spread. Year-dummies are also included.

\section{[Insert Table 4 here]}

In the first column, we regress the spread on free float, and find a negative relationship. This result is consistent with the free-float/trading hypothesis. When the size of the market for the firm's shares is reduced, the frequency of trades and the production of information decrease and the liquidity is reduced. To test more directly the role of controlling shareholders on liquidity, in the second column we include two dummies for controlled firms. The first (second) dummy equals one if the firm is controlled by a family (other controlling shareholder) at the $20 \%$ threshold. Spreads of family-firms (other controlled firms) shares are $4.37 \%(6.22 \%)$ larger on average than spreads of widely-held shares. We further include the percentage of capital held by the first and the second shareholders. We find the spread 
increases (and the depth decreases) with the percentage of the capital held by both the controlling and the second shareholder, confirming the free-float/trading hypothesis but also the adverse selection hypothesis if we suppose that controlling shareholders are informed traders.

We then investigate the impact of separation of ultimate control and ownership on liquidity. Discrepancy between cash flow rights and voting rights is equal to the ratio of voting rights minus cash flow rights to cash flow rights. We find the deviation of control from ownership to have a positive impact on spread and a negative but insignificant impact on depth. Several reasons may explain this result. First, when minority shareholders suspect private benefits to become a large part of the firm's value, they may prefer selling the shares or renounce to buy them. Second, the ultimate shareholder may choose to adopt a poor disclosure policy, to trade on his private information. Both will lead to lower liquidity.

Our results are robust when subsamples by control type are considered. The existence of a controlling shareholder at the $20 \%$ threshold reduces liquidity, whether he is a family or not. The second shareholder has a negative impact on liquidity for family-firms only. The deviation between ultimate control and ownership increases the spread for all the controlled firms, but the impact is more pronounced for family-firms. It does not affect depth. Orders may be posted in the order book in such manner to narrow the spread but with smaller quantities. One explanation is that in the presence of a large control-ownership deviation, most institutional investors do not invest. Thus, transactions are mainly initiated by individual investors, leading to smaller order size. However, as a fraction of these investors are informed, spreads increase. We therefore find evidence for our second hypothesis of reduced liquidity in the presence of controlling shareholders.

\section{Means of enhancing control and market liquidity}

French firms use two main devices to concentrate control, pyramids and double voting rights. We check whether these mechanisms have similar impacts on liquidity. Table 5 (panel A) reports the characteristics of firm-year observations using double voting rights compared to those without double voting rights. With respect to widely-held firms and non-familycontrolled firms, we find little difference in the univariate analysis between firms using double voting rights or not. On the contrary, for family-firms, the free float is significantly greater for firms using double voting rights (46.55\% on average, compared to $35.45 \%$ for firms without double voting rights). This finding is consistent with the fact that families want 
to keep control anyway, and that the use of double voting rights allows them to increase the float of their companies for a given cash flow stake. Family-firms with double voting rights exhibit lower spreads $(2.80 \%$ compared to $3.61 \%$ without double voting rights) and higher average depth $(26,800$ compared to 18,300$)$. Table 5, panel B, compares firms using double voting rights as a unique control enhancing device to firms with no control enhancing device. The results are close to the previous ones: family-firms with double voting rights display larger free floats and reduced spreads.

\section{[Insert Table 5 here]}

Table 5, Panel C compares controlled firms using pyramids to controlled firms without pyramids. Pyramidal structures do not significantly affect the characteristics of non-familycontrolled firms. On the contrary, family-firms controlled by pyramiding are larger, have a larger free-float and a greater turnover. They exhibit higher liquidity: the average spread is $2.09 \%$ for pyramids compared to $3.12 \%$ for other firms and the median depth is 19,700 euros compared to 8,800 for other firms. Table 5, Panel D compares firms using pyramids as a unique means of enhancing control to firms using no control enhancing device. The results are roughly the same as in Panel C. However, the finding of better liquidity for pyramiding firms is of limited interest in an univariate setting, as these firms display a much larger market capitalization, leading to increased liquidity.

We further examine the impact of different means of enhancing control by running regressions explaining our liquidity variables. Table 6 reports the regression coefficients for the total sample.

\section{[Insert Table 6 here]}

In the first set of regressions, we explain the spread by direct ownership variables (as opposed to ultimate ownership variables): percentage of capital owned by the main and the second shareholders, deviation between cash flow rights and control rights. The impact of the two direct ownership variables is similar to that of the ultimate ownership variables in Table 4. However, the direct control/ownership deviation enters the regressions with a significant negative coefficient, whereas, in Table 4, the ultimate deviation displays a positive coefficient. Double voting right shares are the main origin of direct deviation. Ultimate 
deviation is the consequence of both pyramiding and double voting rights. This finding may result from a different impact of these two means of enhancing control on liquidity.

To verify this hypothesis, the next regressions include dummies equal to one if the firm has adopted one of the following control enhancing mechanisms: pyramids, double voting rights, voting caps, dual class shares, and limited partnership. We find that double voting rights have a negative impact on spreads, whereas pyramiding leads to increased spreads. This result is robust to the inclusion of direct or ultimate ownership variables. It is also robust to the inclusion of a dummy for the identity of controlling shareholders. However, depth does not depend on the inclusion of double voting rights and pyramiding.

Dual class shares and limited partnership have no impact on liquidity measures. Voting caps increase both spreads and depths.

Next, as family firms preferably use double voting rights, and other controlling shareholders pyramids, we investigate if the previous findings are invariant whatever the controlling shareholder identity. We run the previous set of regressions for subsamples by ownership structure type (Table 7).

\section{[Insert Table 7 here]}

For widely-held firms, double voting rights have no impact on liquidity. Voting caps increase spreads and depths. Most voting caps (63\%) are adopted by CAC40 firms, which is the most liquid segment of the French market. When including in the regression a dummy that equals one if the firm belongs to the CAC40 index, the voting caps effects disappears. So, for widely held firms, liquidity is neither improved nor diminished by the adoption of any means of enhancing control.

For family-firms, we confirm that direct control/ownership deviation has a negative impact on spreads. Further, double voting rights decrease spreads and pyramiding increases spreads. For non-family-controlled firms, the spread does not depend on direct control/ownership deviation, neither on the double voting right dummy. However, pyramiding increases spreads.

Our results confirm that double voting rights may have a positive impact on liquidity for family-firms. This effect has two origins: first, the free float is larger for family-firms with double voting rights. Double voting rights permit family shareholders to ensure control by holding a lower fraction of the shares. As the negative impact of double voting rights is robust to including the variable float in the regressions, enlarging float is not the unique explanation 
for the positive impact of double voting rights on liquidity. The second reason results from a probable reduction of insider trading. Some informed shareholders will give up selling their shares, because if they did, they would lose their double voting rights. If a significant number of informed shareholders keep away from the market, the asymmetry of information may decrease, resulting in a greater liquidity. Double voting rights, by rewarding long-term shareholders, are also a way of enhancing liquidity for minority shareholders, in the context of small and closely-held firms. It may therefore be beneficial for both controlling and minority shareholders.

To check the robustness of our results, we verify them on a subsample of firms using double voting rights as a unique means of enhancing control and firms using no control enhancing device (Table 8, Panel A). Again, we find that for family-firms, double voting rights have a negative impact on spreads and a positive but insignificant impact on depth. Similarly, on a subsample with firms using pyramids and firms using no control enhancing device, we find that pyramids increase spreads for non-family-controlled firms (Table 8, Panel B). Our results confirm therefore our third hypothesis that the impact of controlownership deviation on liquidity is positive for double voting rights and negative for pyramids.

[Insert Table 8 here]

Ownership structure and adverse selection component of spread

We further investigate the impact of ownership and governance variables on the adverse-selection spread component. If our previous findings result from a variation of the degree of asymmetric information in the presence of a large shareholder and when the control-ownership deviation is high, we should observe a variation in the adverse selection component of the spread.

We use the Euronext intraday database. We identify and exclude the transactions on opening and closing call auctions. The orders carried out on several limits of prices in the order book are identified and aggregated as a single transaction. ${ }^{9}$ Over a one-year period (6 months before and 6 months after) around the year-end 1998, 2000 and 2002, 56.604 million transactions occur for the shares of our sample, among which 6.362 million are executed on at 
least two price limits. The number of observations available a given month differs from one share to another. For example, France Telecom has 143,969 transactions in July 2002, whereas 1475 share-months (out of 11179) have less than 50 transactions.

We use the Huang and Stoll (1997) approach to measure the adverse component of the spread. We denote the price of the transaction at time $t$ as Pt and define Qt to be the buy-sell trade indicator variable for the transaction price, Pt. It equals +1 if the transaction is buyer initiated and -1 if the transaction is seller initiated. As Euronext is an electronic order driven market, the direction of the transactions can be identified in a precise way, by comparing the price and the immediately preceding spread.

$$
P_{t}-P_{t-1}=\frac{S}{2} \times\left(Q_{t}-Q_{t-1}\right)+(\alpha+\beta) \times \frac{S}{2} \times Q_{t}+e_{t}
$$

$\alpha$ and $\beta$, which cannot be estimated separately represent the adverse selection component and the cost of inventory component of the spread as a percentage of the halfspread. S, the traded spread, is estimated with the Huang and Stoll's model for the 11,180 share-month for which at least 50 transactions (call auctions excluded) are available. The adverse selection component of the spread is estimated as:

$$
\text { Adverse selection component }=\frac{\text { Quoted } \text { spread }- \text { estimated spread }}{\text { quoted spread }}
$$

For each share and each of our three periods, we average the adverse selection spread component. All non-positive estimates are taken as equal to 0 .

The sample size for the adverse selection component of the spread (1087 firm-year observations) is therefore smaller than the sample size for spreads and depths (1550). Table 9, Panel A, compares the characteristics of the firm-years for which the adverse component of the spread can be calculated and the other observations. The reduced sample contains $92.61 \%$ of the widely-firms, and only $64.18 \%$ of the family-firms. The firms in the reduced sample are characterized by a larger average market capitalization (2,878 millions euros compared to 97 for the non-included firms). The float is significantly larger (56.21\% compared to $39.20 \%$ ), the main ultimate shareholder holds $38.87 \%$ of the capital $(54.87 \%$ for the non-included firms), and the average spread is $1.73 \%$ (4.70\% for the non-included firms). In general, our reduced sample contains larger and more liquid firms than those of the initial sample.

[Insert Table 9 here] 
We next run regressions to explain the adverse selection spread component to test the hypothesis that larger controlling shareholders and control-ownership deviation are associated with more serious information asymmetry (Table 9, Panel B). We find that the adverse selection component of the spread is increasing with the ultimate and direct percentage of capital held by the main and the second shareholders, confirming that controlling shareholders are informed traders. The ultimate control/ownership deviation increases the adverse component of the spread, for the total sample and the subsamples of family and non familycontrolled firms. The pyramid dummy increases the asymmetric information for the total sample and the family-firms sample. When the controlling shareholder is able to trade on private information to extract private benefits, in particular by adopting a poor disclosure policy, the asymmetric information is higher. On the contrary, we can observe that neither the direct control-ownership deviation, resulting mainly from double voting rights, nor the double voting rights dummy, have a significant impact on the adverse selection component of spread Our previous results on double voting rights hold mainly for family-firms, which are on average smaller than other firms. We can see in Table 9, panel A, that more than one-third of the family-firms are excluded in the calculation of the adverse selection component of the spread. The reduced sample containing mainly larger and more liquid firms, one interpretation could be that the impact of double voting rights on the degree of asymmetric information does exist for small and illiquid firms, for which we are unable to calculate the adverse selection spread component, but is unobservable for larger firms.

\section{Conclusion}

Our study of the ownership-liquidity relation in France contributes to a wider understanding of the impact of ownership structure and corporate governance mechanisms on market liquidity. We study a large sample of French firms by gathering hand collected data on control enhancing devices. French firms are characterized by concentrated ownership and a large use of double voting rights, a specific mechanism rewarding long-term shareholders. We find that liquidity is significantly reduced for closely-held firms, and this result is robust to measuring the controlling shareholding by direct or ultimate ownership, and to taking into account the identity of the controlling shareholder. The deviation between ultimate control and ownership increases the spread and its adverse selection component for all the controlled firms, but the impact is more pronounced for family-firms. 
Pyramiding has a negative impact on spreads for all controlled firms. However, double voting rights are a liquidity enhancing device for family-firms. Double voting rights permit a larger free float for families that want to keep control and prevent informed shareholders from trading on private information. Overall, our study finds that for small family-firms, double voting right shares may be an enhancing control device that has positive consequences for minority shareholders in terms of the liquidity of their shares. 


\section{References}

Attig N., W.M. Fong, Y. Gadhoum and L. Lang, 2006, Effects of large shareholding on information asymmetry and stock liquidity, Journal of Banking and Finance, 30, 10, 28752892

Bebchuk, L., R. Kraakman, and G. Triantis, 2000, Stock pyramids, cross-ownership, and dual class equity: The creation and agency costs of separating control from cash flow rights, in R.K. Morck, ed.: Concentrated Corporate Ownership (University of Chicago Press, Chicago, Il.).

Becht, M., 1999, European corporate governance: Trading of liquidity against control, European Economic Review, 43, 1071-1083

Beny N. L., 2004, A comparative empirical investigation of agency and market theories of insider trading, University of Michigan Legal Working Paper Series.

Bhide A. 1993, The hidden costs of stock market liquidity, Journal of Financial Economics, $34,31-51$.

Biais B., P. Hillion and C. Spatt, 1995, An empirical analysis of the limit order book and the order flow in the Paris Bourse, Journal of Finance, 50, 1655-1689.

Boehmer E., Sanger G. and Varshney S., 2004, Managerial bonding and stock liquidity: an analysis of dual-class firms, Journal of Economics and Finance, 28,1, 117-131

Bollen, N., Smith T., Whaley R., 2003. Modeling the bid/ask spread: measuring the inventory-holding premium. Journal of Financial Economics 72, 97-141.

Bolton, P., Von Thadden, E.-L., 1998, Blocks, liquidity and corporate control. Journal of Finance 53, 1, 1-25.

Brennan, Michael J., Tarun Chordia, and Avanidhar Subrahmanyam, 1998, Alternative factor specifications, security characteristics, and the cross-section of expected returns, Journal of Financial Economics 49, 345-373.

Brockman P. and D.Y. Chung, 2003, Investor protection and firm liquidity, Journal of Finance, 58, 2, 921-938

Claessens S., S. Djankov, J. Fan and L. Lang, 2002, Disentangling the incentive and entrenchment effects of large shareholders, Journal of Finance, 57, 6, 2741-2771

Comerton-Forde, C. and Rydge, J., 2006, Director Holdings, Shareholder Concentration and Illiquidity, Working paper, University of Sydney

Copeland, T. E., Galai, D., 1983. Information effects of the bid-ask spread. Journal of Finance 38, 1457-1469. 
Dahlquist M., L. Pinkowitz, R. Stulz, and R. Williamson, 2003, Corporate governance, investor protection and the home bias, Journal of Financial and Quantitative Analysis, 38,1

Demsetz, H., 1968, The cost of transactions, Quarterly Journal of Economics 20, 267- 291.

Dennis P. et J. Weston, 2001, Who's Informed? An Analysis of Stock Ownership and Informed Trading, AFA 2002

Faccio M. and L. Lang, 2002, The separation of ownership and control: an analysis of ultimate ownership in western European corporations, Journal of Financial Economics, 65, 365-395

Glosten L. R. and Milgrom P. R., 1985, Bid, Ask and Transaction Prices in a Specialist Market with Heterogeneously Informed Traders, Journal of Financial Economics 14, 71100.

Heflin F., and Shaw W. K., 2000, Blockholder Ownership and Market Liquidity, Journal of Financial and Quantitative Analysis, 35, 621-633.

Holmström B. and J. Tirole, 1993, Market liquidity and performance monitoring, Journal of Political Economy, 101, 4, 678-709.

Huang R.D. and H.R. Stoll, 1997, The components of the bid-ask spread: a general approach, Review of Financial Studies, 10, 4, 995-1034.

Kini, Omesh and S. Mian, 1995, Bid-ask spread and ownership structure, Journal of Financial Research, 58, 401-414

La Porta R., Lopez-de-Silanes F., Schleifer A., and R. Vishny, 2000, Investor protection and corporate governance, Journal of Financial Economics, 58, 3-27

La Porta R., Lopez-de-Silanes F., Schleifer A., and R. Vishny, 2002, Investor protection and corporate valuation, Journal of Finance, 57, 3, 1147-1170.

Lin J., G. Sanger and G. Booth, 1995, Trade size and components of the bid-ask spread, Review of Financial Studies, 8, 1153-1183.

Næs R., 2004, Ownership Structure and Stock Market Liquidity, Working Paper 2004/6, Norges Bank

Rubin A., 2007, Ownership level, ownership concentration, and liquidity, forthcoming, Journal of Financial Market

Sarin A., Shastri K. A., and Shastri K., 2000, Ownership structure and stock market liquidity, Working Paper, Santa Clara University.

Stoll, H. R., 2003. Market microstructure. In Constantinides, G., Harris, M. Stulz, R. (Eds.), Handbook of the Economics of Finance. North-Holland, Amsterdam. 


\section{Table 1. Descriptive statistics for ownership of French firms}

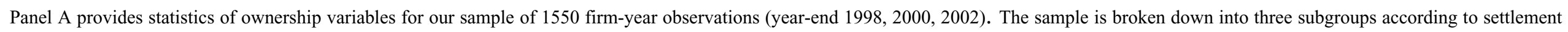

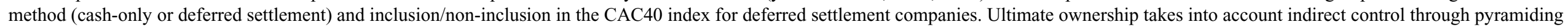

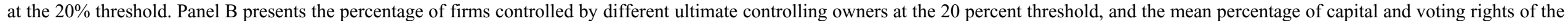
controlling owners.

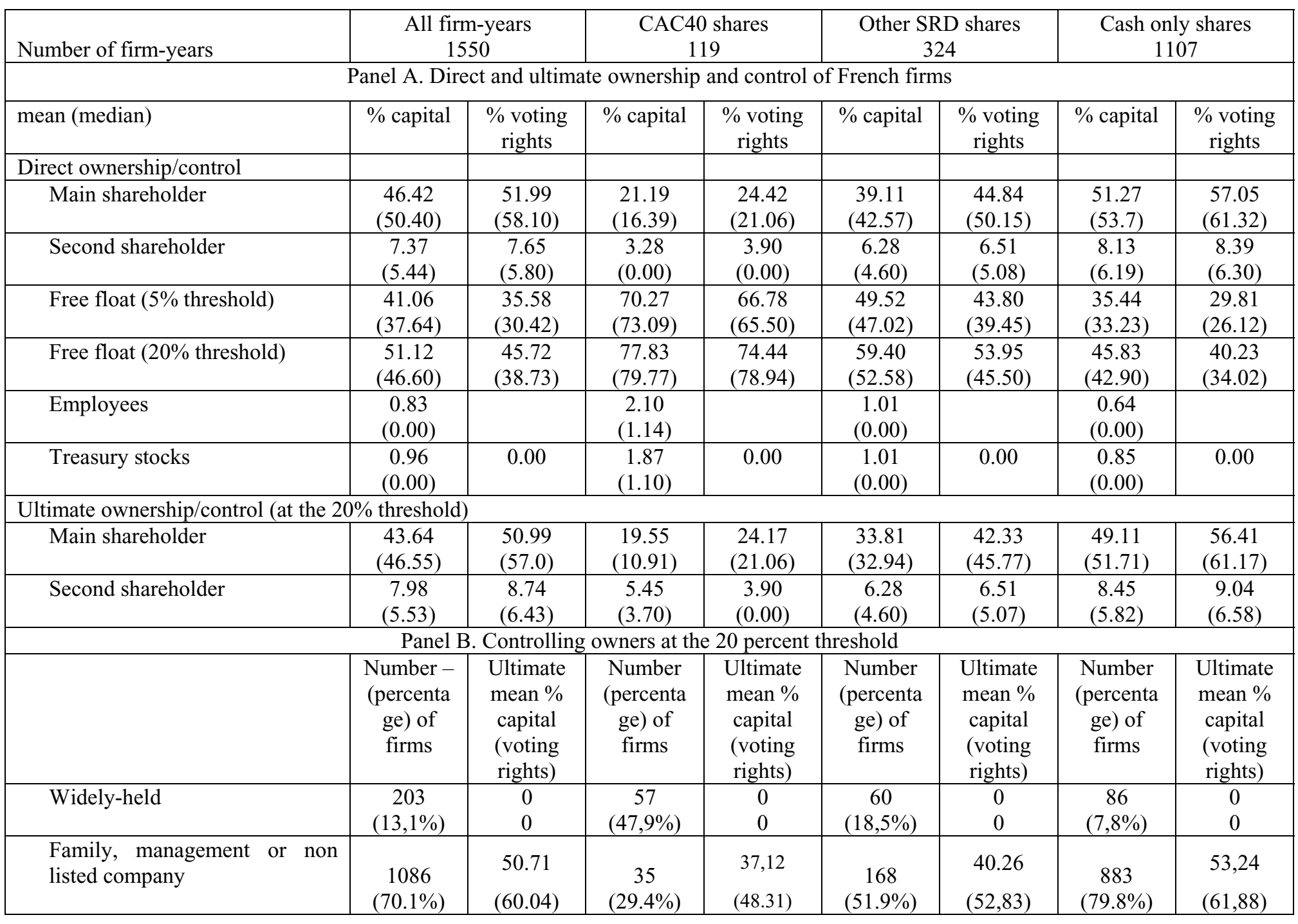




\begin{tabular}{|l|c|c|c|c|c|c|c|c|}
\hline State & 44 & 51.52 & 11 & 41,10 & 17 & 53.91 & 16 & 62,14 \\
& $(2,8 \%)$ & $(55,57)$ & $(9.2 \%)$ & $(46.98)$ & $(5.2 \%)$ & $(57,55)$ & $(1,4 \%)$ & $(63,51)$ \\
\hline Other corporation & 75 & 54.73 & 7 & 32.71 & 34 & 49.28 & 34 & 64.71 \\
& $(4.8 \%)$ & $(57.73)$ & $(5.9 \%)$ & $(35.41)$ & $(10.5 \%)$ & $(54.37)$ & $(3.1 \%)$ & $(65.70)$ \\
\hline Financial institutions & 142 & 43.70 & 9 & 39.05 & 45 & 37.69 & 88 & 47,25 \\
& $(9,2 \%)$ & $(49.70)$ & $(7.6 \%)$ & $(47.60)$ & $(13,9 \%)$ & $(46,15)$ & $(7,9 \%)$ & $(51.82)$ \\
\hline
\end{tabular}




\section{Table 2. Control devices adopted by French firms}

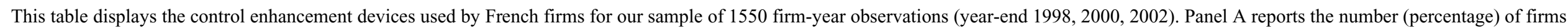
adopting a given control device, the number of firms adopting pyramids and another device, and the number of firms using double voting rights and another device. In panel $\mathrm{B}$, the sample is broken

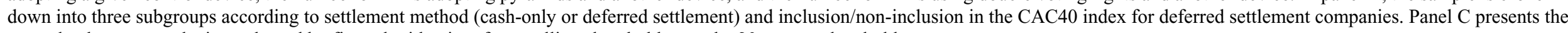
control enhancement devices adopted by firms, by identity of controlling shareholders at the 20 percent threshold.

\begin{tabular}{|c|c|c|c|c|c|c|c|c|}
\hline & $\begin{array}{l}\text { Double } \\
\text { voting } \\
\text { rights }\end{array}$ & $\begin{array}{l}\text { Voting } \\
\text { caps }\end{array}$ & Pyramids & $\begin{array}{l}\text { Dual } \\
\text { class }\end{array}$ & $\begin{array}{l}\text { Limited } \\
\text { partnersh } \\
\text { ip firm }\end{array}$ & None & $\begin{array}{l}\text { Only } \\
\text { double } \\
\text { voting } \\
\text { rights }\end{array}$ & total \\
\hline \multicolumn{9}{|c|}{ Panel A. Number of firms using different control devices } \\
\hline $\begin{array}{l}\text { Number of } \\
\text { observations } \\
\text { (percentage) }\end{array}$ & $\begin{array}{c}1058 \\
(68,3 \%)\end{array}$ & $\begin{array}{c}35 \\
(2,3 \%)\end{array}$ & $\begin{array}{c}287 \\
(18,5 \%)\end{array}$ & $\begin{array}{c}19 \\
(1,2 \%)\end{array}$ & $\begin{array}{c}28 \\
(1,8 \%)\end{array}$ & $\begin{array}{c}316 \\
(20,4)\end{array}$ & $\begin{array}{c}809 \\
(52,2 \%)\end{array}$ & $\begin{array}{c}1550 \\
(100 \%)\end{array}$ \\
\hline $\begin{array}{l}\text { Pyramids and } \\
\text { another device }\end{array}$ & 143 & 3 & & 7 & 0 & & & \\
\hline $\begin{array}{l}\text { Double voting } \\
\text { rights and } \\
\text { another device }\end{array}$ & & 26 & 143 & 19 & 16 & & & \\
\hline \multicolumn{9}{|c|}{ Panel B. Number of firms (percentage) using different control devices by markets } \\
\hline $\begin{array}{l}\text { CAC40 } \\
\text { shares }\end{array}$ & $\begin{array}{c}85 \\
(71,4 \%) \\
\end{array}$ & $\begin{array}{c}22 \\
(18,5 \%) \\
\end{array}$ & $\begin{array}{c}29 \\
(24,4 \%) \\
\end{array}$ & $\begin{array}{c}5 \\
(4,2 \%) \\
\end{array}$ & $\begin{array}{c}6 \\
(5 \%) \\
\end{array}$ & $\begin{array}{c}18 \\
(15,1 \%)\end{array}$ & $\begin{array}{c}37 \\
(31,1 \%) \\
\end{array}$ & $\begin{array}{c}119 \\
(100 \%)\end{array}$ \\
\hline $\begin{array}{l}\text { Other SRD } \\
\text { shares }\end{array}$ & $\begin{array}{c}217 \\
(67,0 \%)\end{array}$ & $\begin{array}{c}9 \\
(2,8 \%)\end{array}$ & $\begin{array}{c}106 \\
(32,7 \%)\end{array}$ & $\begin{array}{c}4 \\
(1,2 \%)\end{array}$ & $\begin{array}{c}6 \\
(1,9 \%)\end{array}$ & $\begin{array}{c}50 \\
(15,4 \%)\end{array}$ & $\begin{array}{c}137 \\
(42,3 \%)\end{array}$ & $\begin{array}{c}324 \\
(100 \%)\end{array}$ \\
\hline $\begin{array}{ll}\begin{array}{l}\text { Cash } \\
\text { shares }\end{array} & \text { only } \\
\end{array}$ & $\begin{array}{c}756 \\
(68,3 \%) \\
\end{array}$ & $\begin{array}{c}4 \\
(0,4 \%) \\
\end{array}$ & $\begin{array}{c}152 \\
(13,7 \%)\end{array}$ & $\begin{array}{c}10 \\
(0,9 \%)\end{array}$ & $\begin{array}{c}16 \\
(1,4 \%) \\
\end{array}$ & $\begin{array}{c}248 \\
(22,4 \%)\end{array}$ & $\begin{array}{c}635 \\
(57,4 \%)\end{array}$ & $\begin{array}{c}1107 \\
(100 \%)\end{array}$ \\
\hline \multicolumn{9}{|c|}{ Panel C. Number of firms (percentage) using different control devices by identity of controlling shareholder } \\
\hline Family & $\begin{array}{c}829 \\
(76,3 \%)\end{array}$ & $\begin{array}{c}8 \\
(0,7 \%) \\
\end{array}$ & $\begin{array}{c}136 \\
(12,5 \%)\end{array}$ & $\begin{array}{c}18 \\
(1,7 \%)\end{array}$ & $\begin{array}{c}9 \\
(0,8 \%)\end{array}$ & $\begin{array}{c}195 \\
(18,0 \%)\end{array}$ & $\begin{array}{c}682 \\
(62,8 \%)\end{array}$ & $\begin{array}{c}1086 \\
(100 \%)\end{array}$ \\
\hline $\begin{array}{l}\text { Financial } \\
\text { institution }\end{array}$ & $\begin{array}{c}65 \\
(45,8 \%) \\
\end{array}$ & $\begin{array}{c}4 \\
(2,8 \%) \\
\end{array}$ & $\begin{array}{c}73 \\
(51,4 \%) \\
\end{array}$ & 0 & $\begin{array}{c}1 \\
(0,7 \%)\end{array}$ & $\begin{array}{c}29 \\
(20,4 \%) \\
\end{array}$ & $\begin{array}{c}33 \\
(23,2 \%) \\
\end{array}$ & $\begin{array}{c}142 \\
(100 \%)\end{array}$ \\
\hline State & $\begin{array}{c}13 \\
(29,5 \%) \\
\end{array}$ & $\begin{array}{c}0 \\
(0 \%) \\
\end{array}$ & $\begin{array}{c}14 \\
(31,8 \%) \\
\end{array}$ & $\begin{array}{c}0 \\
(0 \%) \\
\end{array}$ & $\begin{array}{c}0 \\
(0 \%) \\
\end{array}$ & $\begin{array}{c}20 \\
(45,5 \%) \\
\end{array}$ & $\begin{array}{c}6 \\
(13,6 \%) \\
\end{array}$ & $\begin{array}{c}44 \\
(100 \%) \\
\end{array}$ \\
\hline $\begin{array}{l}\text { Other } \\
\text { corporation }\end{array}$ & $\begin{array}{c}35 \\
(46,7 \%) \\
\end{array}$ & $\begin{array}{c}1 \\
(1,3 \%) \\
\end{array}$ & $\begin{array}{c}64 \\
(85,3 \%) \\
\end{array}$ & $\begin{array}{c}0 \\
(0,0 \%) \\
\end{array}$ & $\begin{array}{c}3 \\
(4,0 \%) \\
\end{array}$ & $\begin{array}{c}4 \\
(5,3 \%) \\
\end{array}$ & $\begin{array}{c}4 \\
(5,3 \%) \\
\end{array}$ & $\begin{array}{c}75 \\
(100 \%) \\
\end{array}$ \\
\hline $\begin{array}{l}\text { Widely-held } \\
\text { firms }\end{array}$ & $\begin{array}{c}116 \\
(57,1 \%) \\
\end{array}$ & $\begin{array}{c}22 \\
(10,8 \%) \\
\end{array}$ & $\begin{array}{c}0 \\
(0 \%) \\
\end{array}$ & $\begin{array}{c}1 \\
(0,5 \%)\end{array}$ & $\begin{array}{c}15 \\
(7,4 \%) \\
\end{array}$ & $\begin{array}{c}68 \\
(33,5 \%) \\
\end{array}$ & $\begin{array}{c}84 \\
(41,4 \%) \\
\end{array}$ & $\begin{array}{c}203 \\
(100 \%) \\
\end{array}$ \\
\hline
\end{tabular}


Table 3. Descriptive statistics for market characteristics of French firms

This table contains 1550 firm-year observations. The sample is broken down by settlement method (cash-only or deferred settlement) and inclusion/non-inclusion in the

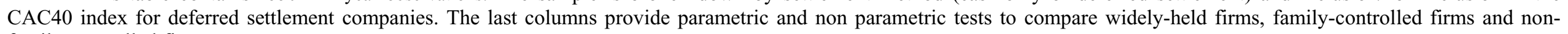

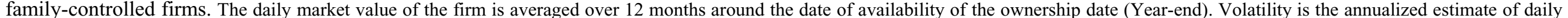

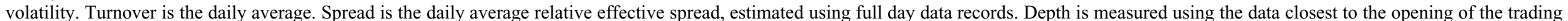
day. All the variables are averaged over 12 months around the year-end.

\begin{tabular}{|c|c|c|c|c|c|c|c|c|c|}
\hline \multirow[t]{2}{*}{ Panel A. All shares } & \multicolumn{2}{|c|}{$\begin{array}{l}\text { Widely-held } \\
\mathrm{N}=203\end{array}$} & \multicolumn{2}{|c|}{$\begin{array}{c}\text { Family-controlled } \\
\mathrm{N}=1086\end{array}$} & \multicolumn{2}{|c|}{$\begin{array}{l}\text { Non-family-controlled } \\
\qquad \mathrm{N}=261\end{array}$} & \multirow{2}{*}{$\begin{array}{l}\begin{array}{l}\text { Family- } \\
\text { controlled vs } \\
\text { Widely-held }\end{array} \\
\begin{array}{l}\text { p-values from } \\
\text { Student test } \\
\text { (median test) }\end{array} \\
\end{array}$} & \multirow{2}{*}{\begin{tabular}{|l|}
$\begin{array}{l}\text { Non-family- } \\
\text { controlled vs } \\
\text { widely-held }\end{array}$ \\
$\begin{array}{l}\text { p-values from } \\
\text { Student test } \\
\text { (median test) }\end{array}$ \\
\end{tabular}} & \multirow{2}{*}{\begin{tabular}{|l}
$\begin{array}{l}\text { Family- } \\
\text { controlled vs } \\
\text { non-family- } \\
\text { controlled }\end{array}$ \\
$\begin{array}{l}\text { p-values from } \\
\text { Student test } \\
\text { (median test) }\end{array}$ \\
\end{tabular}} \\
\hline & Mean & Median & Mean & Median & Mean & Median & & & \\
\hline Market capitalization ( $€$ million) & 6587.3 & 538.3 & 877.51 & 83.09 & 3401.2 & 460.3 & $\begin{array}{r}<.0001 \\
(<.0001) \\
\end{array}$ & \begin{tabular}{r|}
0.0113 \\
$(0.3896$ \\
\end{tabular} & $\begin{array}{r}0.000 \\
(<.0001) \\
\end{array}$ \\
\hline Volatility (average annualized daily estimation) & $55.7 \%$ & $52.1 \%$ & $51.1 \%$ & $47.8 \%$ & $44.8 \%$ & $42.7 \%$ & $\begin{array}{r}0.0039 \\
(0.0014) \\
\end{array}$ & $\begin{array}{r}<.0001 \\
(<.0001) \\
\end{array}$ & $\begin{array}{r}<.0001 \\
(<.0001) \\
\end{array}$ \\
\hline Value Weighted Average Price, (in €) & 54.26 & 31.09 & 68.12 & 28.61 & 64.02 & 47.72 & $\begin{array}{r}0.1185 \\
(0.2420) \\
\end{array}$ & $\begin{array}{r}0.1387 \\
(0.001) \\
\end{array}$ & $\begin{array}{r}0.6527 \\
(<.0001) \\
\end{array}$ \\
\hline Turnover (daily average in $000 €$ ) & $27,326.2$ & 1744.8 & 2051.1 & 39.6 & 8669.7 & 312.0 & $\begin{array}{r}<.0001 \\
(<.0001) \\
\end{array}$ & $\begin{array}{l}<.0001 \\
(0.001) \\
\end{array}$ & $\begin{array}{r}0.0011 \\
(<.0001) \\
\end{array}$ \\
\hline Number of transactions (daily average) & 919.8 & 217.7 & 105.9 & 12.5 & 397.0 & 33.3 & $\begin{array}{r}<.0001 \\
(<.0001) \\
\end{array}$ & $\begin{array}{r}<.0001 \\
(<.0001) \\
\end{array}$ & $\begin{array}{r}<.0001 \\
(<.0001) \\
\end{array}$ \\
\hline $\begin{array}{l}\text { Average relative effective spread - full day's data records, } \\
\text { in } \%\end{array}$ & $1,46 \%$ & $0,64 \%$ & $2.99 \%$ & $2.35 \%$ & $1.97 \%$ & $1.24 \%$ & $\begin{array}{r}<.0001 \\
(<.0001) \\
\end{array}$ & $\begin{array}{r}0.0069 \\
(0.0019) \\
\end{array}$ & $\begin{array}{r}<.0001 \\
(<.0001) \\
\end{array}$ \\
\hline \multirow[t]{2}{*}{ Panel B. CAC 40 shares } & \multicolumn{2}{|c|}{$\begin{array}{c}\text { Widely-held } \\
\mathrm{N}=57\end{array}$} & \multicolumn{2}{|c|}{$\begin{array}{l}\text { Family-controlled } \\
\qquad \mathrm{N}=27\end{array}$} & \multicolumn{2}{|c|}{$\begin{array}{l}\text { Non-family-controlled } \\
\qquad \mathrm{N}=35\end{array}$} & \begin{tabular}{|l|} 
Family- \\
controlled vs \\
Widely-held
\end{tabular} & \begin{tabular}{|l|} 
Non-family- \\
controlled vs \\
widely-held
\end{tabular} & $\begin{array}{l}\text { Family- } \\
\text { controlled vs } \\
\text { non-family- } \\
\text { controlled } \\
\end{array}$ \\
\hline & Mean & Median & Mean & Median & Mean & Median & $\begin{array}{l}\text { p-values from } \\
\text { Student test } \\
\text { (median test) }\end{array}$ & \begin{tabular}{|l|} 
p-values from \\
Student test \\
(median test)
\end{tabular} & $\begin{array}{l}\text { p-values from } \\
\text { Student test } \\
\text { (median test) }\end{array}$ \\
\hline Market capitalization ( $€$ million) & $21,292.5$ & $14,068.3$ & $19,627.9$ & $13,941.5$ & $17,983.5$ & $9,944.6$ & $\begin{array}{r}0.2750 \\
(0.1428) \\
\end{array}$ & \begin{tabular}{|r|}
0.9592 \\
$(0.4082)$ \\
\end{tabular} & $\begin{array}{r}0.4211 \\
(0.1020) \\
\end{array}$ \\
\hline Volatility (average annualized daily estimation) & $44.75 \%$ & $45.49 \%$ & $48.37 \%$ & $44.85 \%$ & $44.75 \%$ & $45.49 \%$ & $\begin{array}{r}0.3965 \\
(0.4154) \\
\end{array}$ & $\begin{array}{r}0.4900 \\
(0.4082) \\
\end{array}$ & $\begin{array}{r}0.9656 \\
(0.3997) \\
\end{array}$ \\
\hline Value Weighted Average Price, (in €) & 90.57 & 74.59 & 111.54 & 67.29 & 72.28 & 52.45 & $\begin{array}{r}0.4154 \\
(0.2609) \\
\end{array}$ & $\begin{array}{r}0.0554 \\
(0.0053) \\
\end{array}$ & $\begin{array}{r}0.0539 \\
(0.1020) \\
\end{array}$ \\
\hline Turnover (daily average in $000 €$ ) & $90,397.2$ & $61,956.2$ & $55,751.7$ & $36,902.8$ & $58,150.6$ & $32,965.6$ & 0.0093 & 0.2471 & 0.3540 \\
\hline
\end{tabular}




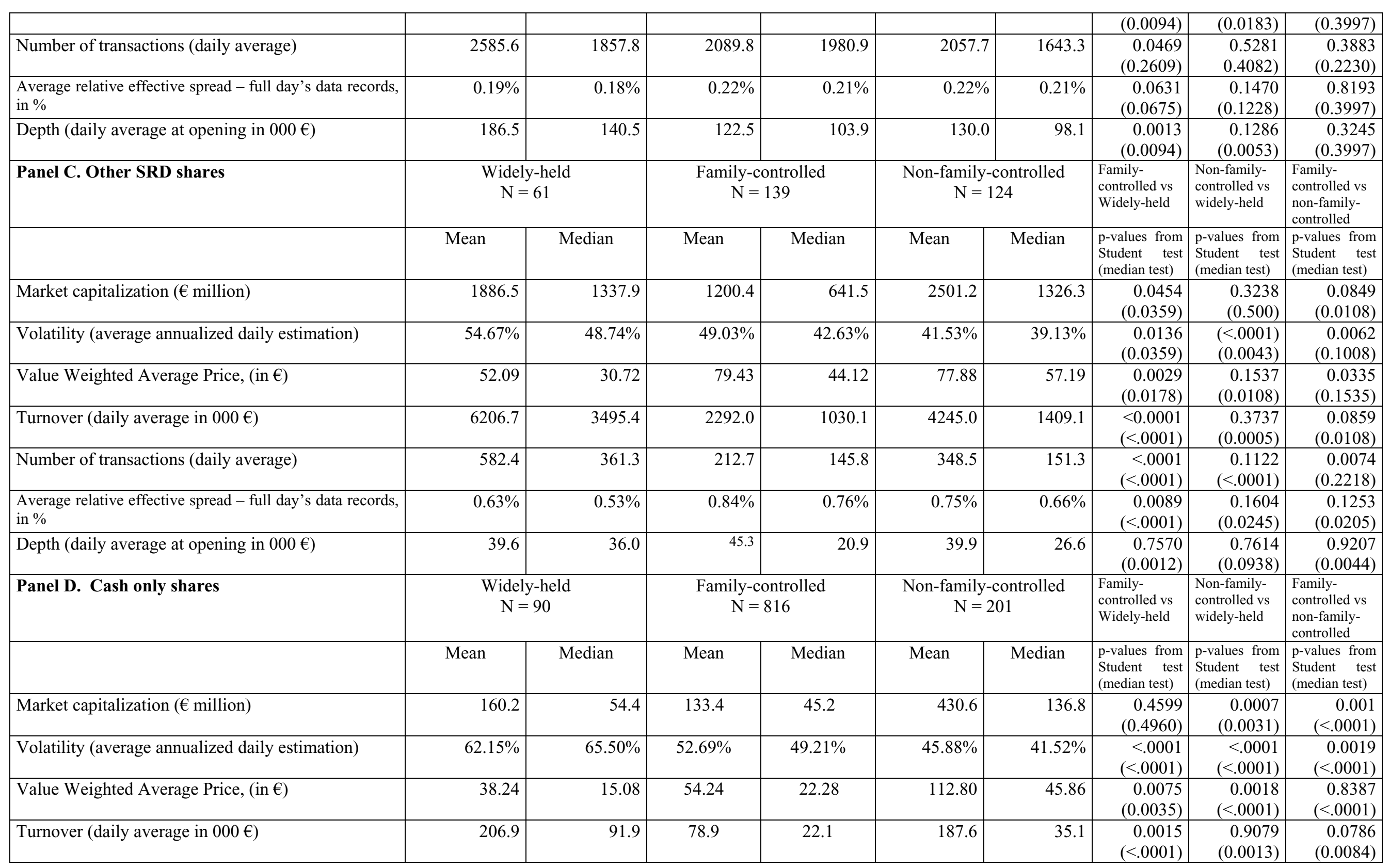




\begin{tabular}{|c|c|c|c|c|c|c|c|c|c|}
\hline Number of transactions (daily average) & 44.2 & 33.0 & 16.59 & 9.07 & 18.5 & 8.0 & $\begin{array}{r}<.0001 \\
(<.0001) \\
\end{array}$ & $\begin{aligned}<<.0001 \\
(<.0001)\end{aligned}$ & $\begin{array}{r}0.2751 \\
(0.3526)\end{array}$ \\
\hline $\begin{array}{l}\text { Average relative effective spread - full day's data records, } \\
\text { in } \%\end{array}$ & $2.82 \%$ & $2.08 \%$ & $3.56 \%$ & $2.84 \%$ & $3.12 \%$ & $2.38 \%$ & $\begin{array}{r}0.0122 \\
(0.0893) \\
\end{array}$ & $\begin{array}{r}0.3410 \\
(0.3920)\end{array}$ & $\begin{array}{r}0.0934 \\
(0.0511) \\
\end{array}$ \\
\hline Depth (daily average at opening in $000 €$ ) & 14.0 & 8.7 & 17.5 & 7.7 & 45.0 & 11.8 & $\begin{array}{r}0.0075 \\
(0.2490)\end{array}$ & $\begin{array}{r}0.0047 \\
(0.0271)\end{array}$ & $\begin{array}{r}0.0173 \\
(<0.0001)\end{array}$ \\
\hline
\end{tabular}




\section{Table 4. Controlling shareholders and liquidity}

This table reports OLS regressions that relate liquidity to ownership and governance characteristics for our sample of 1550 firm-year observations. Liquidity is represented by either effective

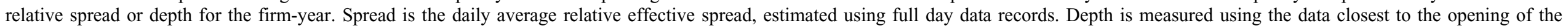

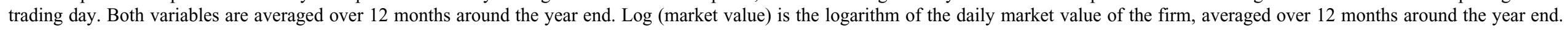

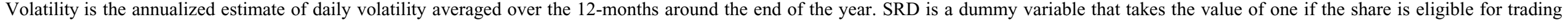

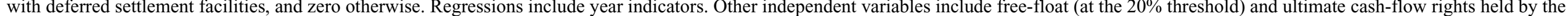

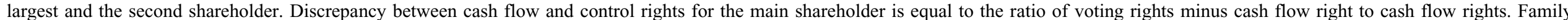

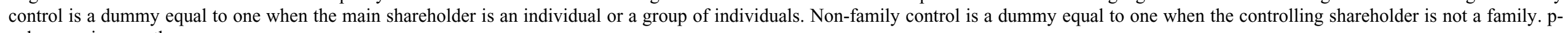
values are in parentheses.

\begin{tabular}{|c|c|c|c|c|c|c|c|c|c|c|c|}
\hline & \multicolumn{5}{|c|}{ Total sample } & \multicolumn{3}{|c|}{ Family-controlled firms } & \multicolumn{3}{|c|}{ Non-family controlled firms } \\
\hline Models & 1 & 2 & 3 & 4 & 5 & 6 & 7 & 8 & 9 & 10 & 11 \\
\hline Variables & Spread & Spread & Spread & Depth & Depth & Spread & Spread & Depth & Spread & Spread & Depth \\
\hline Intercept & $\begin{array}{c}0.1229 \\
(<.0001)\end{array}$ & $\begin{array}{c}0.1110 \\
(<.0001)\end{array}$ & $\begin{array}{c}0.1072 \\
(<.0001)\end{array}$ & $\begin{array}{c}3.1395 \\
(<.0001)\end{array}$ & $\begin{array}{c}3.2741 \\
(<.0001)\end{array}$ & $\begin{array}{c}0.1505 \\
(<.0001)\end{array}$ & $\begin{array}{c}0.1167 \\
(<.0001) \\
\end{array}$ & $\begin{array}{c}3.6908 \\
(<.0001)\end{array}$ & $\begin{array}{c}0.09143 \\
(<.0001)\end{array}$ & $\begin{array}{c}0.07876 \\
(<.0001) \\
\end{array}$ & $\begin{array}{c}3.5283 \\
(<.0001)\end{array}$ \\
\hline \multicolumn{12}{|l|}{ Control variables } \\
\hline Log (market value) & $\begin{array}{l}-0.00552 \\
(<.0001)\end{array}$ & $\begin{array}{l}-0.00544 \\
(<.0001) \\
\end{array}$ & $\begin{array}{l}-0.00547 \\
(<.0001) \\
\end{array}$ & $\begin{array}{c}0.3606 \\
(<.0001) \\
\end{array}$ & $\begin{array}{c}0.3552 \\
(<.0001) \\
\end{array}$ & $\begin{array}{l}-0.00696 \\
(<.0001) \\
\end{array}$ & $\begin{array}{r}-0.00669 \\
(<.0001) \\
\end{array}$ & $\begin{array}{c}0.3201 \\
(<.0001) \\
\end{array}$ & $\begin{array}{l}-0.00410 \\
(<.0001) \\
\end{array}$ & $\begin{array}{c}-0.00402 \\
(<.0001) \\
\end{array}$ & $\begin{array}{c}0.3700 \\
(<.0001) \\
\end{array}$ \\
\hline Volatility & $\begin{array}{c}0.03014 \\
(<.0001) \\
\end{array}$ & $\begin{array}{c}0.02804 \\
(<.0001) \\
\end{array}$ & $\begin{array}{c}0.0300 \\
(<.0001) \\
\end{array}$ & $\begin{array}{c}-0.2887 \\
(0.0053) \\
\end{array}$ & $\begin{array}{c}-0.2769 \\
(0.0074) \\
\end{array}$ & $\begin{array}{c}0.02969 \\
(<.0001) \\
\end{array}$ & $\begin{array}{c}0.02978 \\
(<.0001) \\
\end{array}$ & $\begin{array}{c}-0.2623 \\
(0.0252) \\
\end{array}$ & $\begin{array}{c}0.04662 \\
(<.0001) \\
\end{array}$ & $\begin{array}{c}0.04836 \\
(<.0001) \\
\end{array}$ & $\begin{array}{c}-0.3180 \\
(0.3498) \\
\end{array}$ \\
\hline SRD & $\begin{array}{l}-0.00432 \\
(0.0005) \\
\end{array}$ & $\begin{array}{l}-0.00713 \\
(<.0001) \\
\end{array}$ & $\begin{array}{c}-0.005 \\
(<.0001) \\
\end{array}$ & $\begin{array}{c}0.1448 \\
(0.0109) \\
\end{array}$ & $\begin{array}{c}0.1300 \\
(0.0244) \\
\end{array}$ & $\begin{array}{c}-0.00199 \\
(0.2115) \\
\end{array}$ & $\begin{array}{r}-0.00252 \\
(0.1161) \\
\end{array}$ & $\begin{array}{c}0.2044 \\
(0.0025) \\
\end{array}$ & $\begin{array}{l}-0.01065 \\
(<.0001) \\
\end{array}$ & $\begin{array}{l}-0.01144 \\
(<.0001) \\
\end{array}$ & $\begin{array}{l}-0.2028 \\
(0.2230) \\
\end{array}$ \\
\hline Year 2000 & $\begin{array}{c}0.0001162 \\
(0.9015)\end{array}$ & $\begin{array}{c}0.000085 \\
(0.9300)\end{array}$ & $\begin{array}{l}0.00018 \\
(0.8468)\end{array}$ & $\begin{array}{l}-0.09437 \\
(0.0284)\end{array}$ & $\begin{array}{l}-0.09667 \\
(0.0244)\end{array}$ & $\begin{array}{l}0.00129 \\
(0.2572)\end{array}$ & $\begin{array}{c}0.00095 \\
0.4062 \\
\end{array}$ & $\begin{array}{r}-0.08047 \\
(0.0958)\end{array}$ & $\begin{array}{c}-0.00168 \\
(0.4245)\end{array}$ & $\begin{array}{c}-0.0018 \\
0.3962 \\
\end{array}$ & $\begin{array}{r}-0.08042 \\
(0.5688)\end{array}$ \\
\hline Year 2002 & $\begin{array}{c}0.00488 \\
(<.0001) \\
.\end{array}$ & $\begin{array}{c}0.00476 \\
(<.0001) \\
\end{array}$ & $\begin{array}{c}0.00452 \\
(<.0001) \\
\end{array}$ & $\begin{array}{c}-0.2367 \\
(<.0001) \\
\end{array}$ & $\begin{array}{l}-0.24037 \\
(<.0001) \\
\end{array}$ & $\begin{array}{c}0.00715 \\
(<.0001) \\
\end{array}$ & $\begin{array}{l}0.00668 \\
(<.0001) \\
\end{array}$ & $\begin{array}{c}-0.2222 \\
(<.0001) \\
\end{array}$ & $\begin{array}{c}-0.000656 \\
(0.7723) \\
\end{array}$ & $\begin{array}{c}-0.00134 \\
(0.5569) \\
\end{array}$ & $\begin{array}{c}-0.3556 \\
(0.020) \\
\end{array}$ \\
\hline Free Float (at the $20 \%$ threshold) & $\begin{array}{c}-0.01611 \\
(<.0001) \\
\end{array}$ & & & & & $\begin{array}{l}-0.02367 \\
(<.0001) \\
\end{array}$ & & & $\begin{array}{l}-0.01197 \\
(0.0017) \\
\end{array}$ & & \\
\hline \multicolumn{12}{|l|}{ Ultimate ownership variables } \\
\hline Main shareholder & & & $\begin{array}{c}0.0001833 \\
(<.0001)\end{array}$ & $\begin{array}{l}-0.00293 \\
(<.0001) \\
\end{array}$ & $\begin{array}{l}-0.00229 \\
(0.0472) \\
\end{array}$ & & $\begin{array}{l}0.00030 \\
(<.0001) \\
\end{array}$ & $\begin{array}{r}-0.00098 \\
(0.4626) \\
\end{array}$ & & $\begin{array}{l}0.00011 \\
(0.0163) \\
\end{array}$ & $\begin{array}{r}-0.00741 \\
(0.0161) \\
\end{array}$ \\
\hline Second shareholder & & & $\begin{array}{c}0.0001111 \\
(0.0141) \\
\end{array}$ & $\begin{array}{r}-0.00629 \\
(0.0021) \\
\end{array}$ & $\begin{array}{r}-0.00624 \\
(0.0066) \\
\end{array}$ & & $\begin{array}{l}0.00025 \\
(<.0001) \\
\end{array}$ & $\begin{array}{r}-0.00632 \\
(0.0121) \\
\end{array}$ & & $\begin{array}{r}-0.00003 \\
(0.7563) \\
\end{array}$ & $\begin{array}{r}-0.00971 \\
(0.1401) \\
\end{array}$ \\
\hline $\begin{array}{l}\text { Discrepancy between cash flow and } \\
\text { control rights for the main } \\
\text { shareholder }\end{array}$ & & & $\begin{array}{c}0.00178 \\
(0.0316)\end{array}$ & $\begin{array}{c}-0.05070 \\
(0.1702)\end{array}$ & $\begin{array}{l}-0.03029 \\
(0.4687)\end{array}$ & & $\begin{array}{l}0.00678 \\
(<.0001)\end{array}$ & $\begin{array}{l}0.05170 \\
(0.4085)\end{array}$ & & $\begin{array}{l}0.00205 \\
(0.0723)\end{array}$ & $\begin{array}{c}-0.08276 \\
(0.2698)\end{array}$ \\
\hline \multicolumn{12}{|l|}{ Identity of controlling owner } \\
\hline Family control dummy & & $\begin{array}{l}0.00437 \\
(0.0005)\end{array}$ & $\begin{array}{c}-0.00324 \\
(0.0011)\end{array}$ & & $\begin{array}{c}-0.1055 \\
(0.2273)\end{array}$ & & & & & & \\
\hline Non-family control dummy & & $\begin{array}{c}0.00622 \\
(<.0001) \\
\end{array}$ & & & $\begin{array}{l}0.05481 \\
(0.5636) \\
\end{array}$ & & & & & & \\
\hline Number of observations & 1549 & 1549 & 1549 & 1541 & 1541 & 1086 & 1086 & 1082 & 260 & 260 & 256 \\
\hline Adjusted $\mathrm{R}^{2}$ & 0.5960 & 0.5688 & 0.5910 & 0.6432 & 0.6453 & 0.5865 & 0.5814 & 0.5592 & 0.6226 & 0.6171 & 0.4356 \\
\hline
\end{tabular}


Table 5. Market characteristics according to the means of enhancing control by types of controlling owners

Panel A reports the characteristics of firm-year observations using double voting rights compared to those without double voting rights. Panel B compares the characteristics of firm-year

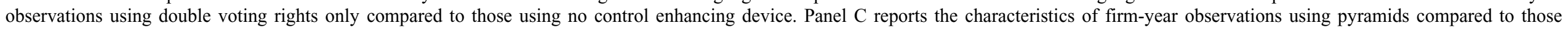

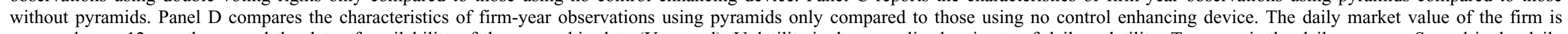

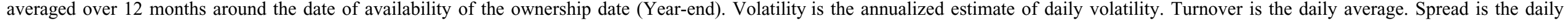

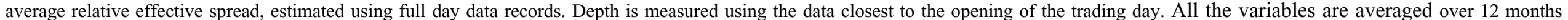
around the year-end. The last columns provide parametric and non parametric tests to compare firms with and without double voting rights.

\begin{tabular}{|c|c|c|c|c|c|c|c|c|c|}
\hline \multicolumn{10}{|c|}{ Panel A. Characteristics of the firms using double voting rights } \\
\hline \multirow[b]{2}{*}{ mean (median) } & \multicolumn{3}{|c|}{ Widely-held } & \multicolumn{3}{|c|}{ Family-controlled } & \multicolumn{3}{|c|}{ Non-family-controlled } \\
\hline & $\begin{array}{l}\text { With double } \\
\text { voting } \\
\text { rights }\end{array}$ & $\begin{array}{l}\text { Without } \\
\text { double } \\
\text { voting } \\
\text { rights }\end{array}$ & $\begin{array}{l}\mathrm{p} \text {-values from } \\
\text { Student test } \\
\text { (median test) }\end{array}$ & $\begin{array}{l}\text { With } \\
\text { double } \\
\text { voting } \\
\text { rights }\end{array}$ & $\begin{array}{l}\text { Without } \\
\text { double } \\
\text { voting } \\
\text { rights }\end{array}$ & $\begin{array}{l}\mathrm{p} \text {-values from } \\
\text { Student test } \\
\text { (median test) }\end{array}$ & $\begin{array}{c}\text { With } \\
\text { double } \\
\text { voting } \\
\text { rights }\end{array}$ & $\begin{array}{l}\text { Without } \\
\text { double } \\
\text { voting } \\
\text { rights }\end{array}$ & $\begin{array}{c}\mathrm{p} \text {-values } \\
\text { from Student } \\
\text { test (median } \\
\text { test) }\end{array}$ \\
\hline \multicolumn{10}{|c|}{ All firms } \\
\hline Number of observations & 116 & 87 & & 829 & 257 & & 148 & 113 & \\
\hline Market capitalization (€ million) & $\begin{array}{l}7,799 \\
(566)\end{array}$ & $\begin{array}{l}4,972 \\
(469)\end{array}$ & $\begin{array}{c}0.1792 \\
(0.3580)\end{array}$ & $\begin{array}{l}908 \\
(84)\end{array}$ & $\begin{array}{l}778 \\
(68)\end{array}$ & $\begin{array}{c}0.6110 \\
(0.3087)\end{array}$ & $\begin{array}{l}4,646 \\
(623)\end{array}$ & $\begin{array}{l}2,428 \\
(388)\end{array}$ & $\begin{array}{c}0.1153 \\
(0.0470)\end{array}$ \\
\hline Float (20\% Threshold), in \% of capital & $\begin{array}{c}100 \\
(100)\end{array}$ & $\begin{array}{c}100 \\
(100)\end{array}$ & & $\begin{array}{c}46.55 \\
(45.45)\end{array}$ & $\begin{array}{c}35.45 \\
(37.05)\end{array}$ & $\begin{array}{r}<.0001 \\
(<.0001) \\
<\end{array}$ & $\begin{array}{c}45.12 \\
(43.15)\end{array}$ & $\begin{array}{c}42.27 \\
(43.61)\end{array}$ & $\begin{array}{c}0.3339 \\
(0.3745)\end{array}$ \\
\hline Turnover (daily average in $000 €$ ) & $\begin{array}{l}33,629 \\
(3,347)\end{array}$ & $\begin{array}{l}18,923 \\
(1,143)\end{array}$ & $\begin{array}{c}0.0898 \\
(0.1126)\end{array}$ & $\begin{array}{c}1,980 \\
(45)\end{array}$ & $\begin{array}{c}2,280 \\
(23)\end{array}$ & $\begin{array}{c}0.790 \\
(0.0002)\end{array}$ & $\begin{array}{c}12,712 \\
(437)\end{array}$ & $\begin{array}{l}5,583 \\
(268)\end{array}$ & $\begin{array}{c}0.1019 \\
(0.1770)\end{array}$ \\
\hline Average relative effective spread - full day's data records & $\begin{array}{c}1.46 \% \\
(0.61 \%) \\
\end{array}$ & $\begin{array}{c}1.46 \% \\
(0.77 \%) \\
\end{array}$ & $\begin{array}{c}0.9993 \\
(0.3138) \\
\end{array}$ & $\begin{array}{c}2.80 \% \\
(2.17 \%) \\
\end{array}$ & $\begin{array}{c}3.61 \% \\
(2.90 \%) \\
\end{array}$ & $\begin{array}{r}<.0001 \\
(<.0001) \\
\end{array}$ & $\begin{array}{c}1.78 \% \\
(1.24 \%) \\
\end{array}$ & $\begin{array}{c}2.11 \% \\
(1.23 \%) \\
\end{array}$ & $\begin{array}{c}0.2233 \\
(0.4718) \\
\end{array}$ \\
\hline Depth (daily average at opening in $000 €$ ) & \begin{tabular}{|c|}
80.3 \\
$(31.8)$ \\
\end{tabular} & $\begin{array}{c}52.6 \\
(22.2) \\
\end{array}$ & $\begin{array}{c}0.0488 \\
(0.1126) \\
\end{array}$ & $\begin{array}{l}26.8 \\
(9.8) \\
\end{array}$ & $\begin{array}{l}18.3 \\
(9.1) \\
\end{array}$ & $\begin{array}{c}0.0536 \\
(0.1257) \\
\end{array}$ & $\begin{array}{c}52.6 \\
(21.4) \\
\end{array}$ & $\begin{array}{c}67.9 \\
(18.7) \\
\end{array}$ & $\begin{array}{c}0.3998 \\
(0.2888) \\
\end{array}$ \\
\hline \multicolumn{10}{|c|}{ Panel B. Firms using double voting rights only compared to firms using no control enhancing device } \\
\hline Number of observations & 38 & 51 & & 401 & 160 & & 24 & 39 & \\
\hline Market capitalization ( $€$ million) & $\begin{array}{l}2,371 \\
(217)\end{array}$ & $\begin{array}{l}1,737 \\
(204)\end{array}$ & $\begin{array}{c}0.4957 \\
(0.4638)\end{array}$ & $\begin{array}{c}659 \\
(627)\end{array}$ & $\begin{array}{l}757 \\
(41)\end{array}$ & $\begin{array}{c}0.8021 \\
(0.0081)\end{array}$ & $\begin{array}{l}553 \\
(82)\end{array}$ & $\begin{array}{l}3,379 \\
(295)\end{array}$ & $\begin{array}{c}0.1269 \\
(0.0249)\end{array}$ \\
\hline Float ( $20 \%$ Threshold), in $\%$ of capital & $\begin{array}{c}100 \\
(100)\end{array}$ & $\begin{array}{c}100 \\
(100)\end{array}$ & $\begin{array}{c}0.3953 \\
(0.1979) \\
\end{array}$ & $\begin{array}{c}45.98 \\
(44.87) \\
\end{array}$ & $\begin{array}{c}36.84 \\
(37.22) \\
\end{array}$ & $\begin{array}{r}<.0001 \\
(<.0001) \\
\end{array}$ & $\begin{array}{c}39.34 \\
(31.27) \\
\end{array}$ & $\begin{array}{c}43.54 \\
(42.90) \\
\end{array}$ & $\begin{array}{c}0.5201 \\
(0.1758) \\
\end{array}$ \\
\hline \multicolumn{10}{|l|}{ Float ( $5 \%$ Threshold), in $\%$ of capital } \\
\hline Turnover (daily average in $000 €$ ) & $\begin{array}{l}8,276 \\
(632)\end{array}$ & $\begin{array}{l}6,422 \\
(552)\end{array}$ & $\begin{array}{c}0.5998 \\
(0.3025)\end{array}$ & $\begin{array}{l}1,204 \\
(37)\end{array}$ & $\begin{array}{c}2,258 \\
(15)\end{array}$ & $\begin{array}{c}0.3417 \\
(0.0028)\end{array}$ & $\begin{array}{l}190 \\
(27)\end{array}$ & $\begin{array}{c}5,506 \\
(56)\end{array}$ & $\begin{array}{c}0.1171 \\
(0.0740)\end{array}$ \\
\hline Average relative effective spread - full day's data records, in \% & $1.67 \%$ & $1.76 \%$ & 0.5157 & $2.85 \%$ & $4.15 \%$ & $<.0001$ & $2.88 \%$ & $2.18 \%$ & 0.1892 \\
\hline
\end{tabular}




\begin{tabular}{|c|c|c|c|c|c|c|c|c|c|}
\hline & $(1.01)$ & $(1.24)$ & $(0.1175)$ & $(2.38)$ & $(3.49)$ & $(<.0001)$ & $(2.47)$ & $(1.47)$ & $(0.0502)$ \\
\hline Depth (daily average at opening in $000 €$ ) & $\begin{array}{c}38.1 \\
(20.1)\end{array}$ & $\begin{array}{c}30.2 \\
(15.4)\end{array}$ & $\begin{array}{c}0.3836 \\
(0.1727)\end{array}$ & $\begin{array}{l}18.8 \\
(9.3)\end{array}$ & $\begin{array}{l}17.8 \\
(7.3)\end{array}$ & $\begin{array}{c}0.8277 \\
(0.0048)\end{array}$ & $\begin{array}{c}20.8 \\
(11.0)\end{array}$ & $\begin{array}{c}35.3 \\
(18.0)\end{array}$ & $\begin{array}{c}0.2171 \\
(0.1505)\end{array}$ \\
\hline
\end{tabular}

\begin{tabular}{|c|c|c|c|c|c|c|}
\hline \multicolumn{7}{|l|}{ Panel C. Characteristics of the firms using pyramids } \\
\hline \multirow[b]{2}{*}{ mean (median) } & \multicolumn{3}{|c|}{ Family-controlled } & \multicolumn{3}{|c|}{ Non-family-controlled } \\
\hline & $\begin{array}{c}\text { With } \\
\text { pyramid }\end{array}$ & $\begin{array}{l}\text { Without } \\
\text { pyramid }\end{array}$ & $\begin{array}{l}\mathrm{p} \text {-values from } \\
\text { Student test } \\
\text { (median test) }\end{array}$ & $\begin{array}{c}\text { With } \\
\text { pyramid }\end{array}$ & $\begin{array}{l}\text { Without } \\
\text { pyramid }\end{array}$ & $\begin{array}{c}\mathrm{p} \text {-values } \\
\text { from Student } \\
\text { test (median } \\
\text { test) }\end{array}$ \\
\hline \multicolumn{7}{|c|}{ All firms } \\
\hline Number of observations & 136 & 950 & & 151 & 110 & \\
\hline Market capitalization ( $€$ million) & $\begin{array}{l}1845 \\
(375)\end{array}$ & $\begin{array}{l}739 \\
(63)\end{array}$ & $\begin{array}{c}0.0028 \\
(<.0001)\end{array}$ & $\begin{array}{l}2191 \\
(597)\end{array}$ & $\begin{array}{l}3932 \\
(264)\end{array}$ & $\begin{array}{c}0.5000 \\
(0.0072)\end{array}$ \\
\hline Float (20\% Threshold), in \% of capital & $\begin{array}{c}36.5 \\
(37.4) \\
\end{array}$ & $\begin{array}{c}44.99 \\
(44.06) \\
\end{array}$ & $\begin{array}{c}<.0001 \\
(0.0051) \\
\end{array}$ & $\begin{array}{c}43.10 \\
(41.40) \\
\end{array}$ & $\begin{array}{c}44.06 \\
(43.61) \\
\end{array}$ & $\begin{array}{c}0.7453 \\
(0.3810) \\
\end{array}$ \\
\hline Turnover (daily average in $000 €$ ) & $\begin{array}{l}4312 \\
(123)\end{array}$ & $\begin{array}{l}1727 \\
(35)\end{array}$ & $\begin{array}{c}0.0197 \\
(<.0001)\end{array}$ & $\begin{array}{l}7679 \\
(591)\end{array}$ & $\begin{array}{l}10029 \\
(102)\end{array}$ & $\begin{array}{c}0.5846 \\
(0.0072)\end{array}$ \\
\hline Average relative effective spread - full day's data records, in $\%$ & $\begin{array}{c}2.09 \\
(1.63)\end{array}$ & $\begin{array}{c}3.12 \\
(2.46)\end{array}$ & $\begin{array}{l}<0.0001 \\
(<.0001)\end{array}$ & $\begin{array}{c}1.78 \\
(0.99)\end{array}$ & $\begin{array}{c}2.22 \\
(1.59)\end{array}$ & $\begin{array}{c}0.1177 \\
(0.0002)\end{array}$ \\
\hline Depth (daily average at opening in $000 €$ ) & $\begin{array}{c}30.7 \\
(19.7)\end{array}$ & $\begin{array}{l}23.9 \\
(8.8)\end{array}$ & $\begin{array}{c}0.1035 \\
(<.0001)\end{array}$ & $\begin{array}{c}68.4 \\
(22.3)\end{array}$ & $\begin{array}{c}51.5 \\
(18.2)\end{array}$ & $\begin{array}{c}0.3503 \\
(0.0566)\end{array}$ \\
\hline \multicolumn{7}{|c|}{ Firms using pyramids only compared to firms using no control enhancing device } \\
\hline Number of observations & 42 & 160 & & 68 & 39 & \\
\hline Market capitalization ( $€$ million) & $\begin{array}{c}504 \\
(274)\end{array}$ & $\begin{array}{l}757 \\
(41) \\
\end{array}$ & $\begin{array}{c}0.4569 \\
(<.0001)\end{array}$ & $\begin{array}{l}1793 \\
(298)\end{array}$ & $\begin{array}{l}3379 \\
(295)\end{array}$ & $\begin{array}{c}0.4038 \\
(0.4494)\end{array}$ \\
\hline Float ( $20 \%$ Threshold), in $\%$ of capital & $\begin{array}{c}26.36 \\
(20.00)\end{array}$ & $\begin{array}{c}36.84 \\
(37.22)\end{array}$ & $\begin{array}{c}0.0022 \\
(0.0190)\end{array}$ & $\begin{array}{c}38.83 \\
(38.88)\end{array}$ & $\begin{array}{c}46.54 \\
(42.90)\end{array}$ & $\begin{array}{c}0.3439 \\
(0.2486)\end{array}$ \\
\hline Turnover (daily average in $000 €$ ) & $\begin{array}{l}330 \\
(39) \\
\end{array}$ & $\begin{array}{c}2858 \\
(15) \\
\end{array}$ & $\begin{array}{c}0.1383 \\
(0.1497)\end{array}$ & $\begin{array}{l}4622 \\
(117) \\
\end{array}$ & $\begin{array}{c}5506 \\
(56) \\
\end{array}$ & $\begin{array}{c}0.8062 \\
(0.1770)\end{array}$ \\
\hline Average relative effective spread - full day's data records, in \% & $\begin{array}{c}2.83 \\
(2.34) \\
\end{array}$ & $\begin{array}{c}4.15 \\
(3.49) \\
\end{array}$ & $\begin{array}{c}0.0007 \\
(0.0028)\end{array}$ & $\begin{array}{c}2.55 \\
(1.36)\end{array}$ & $\begin{array}{c}2.18 \\
(1.47)\end{array}$ & $\begin{array}{c}0.4638 \\
(0.3925) \\
\end{array}$ \\
\hline Depth (daily average at opening in $000 €$ ) & $\begin{array}{c}21.7 \\
(16.0)\end{array}$ & $\begin{array}{l}17.8 \\
(7.3)\end{array}$ & $\begin{array}{c}0.3912 \\
(<.0001)\end{array}$ & $\begin{array}{c}84.3 \\
(16.9)\end{array}$ & $\begin{array}{c}35.3 \\
(18.0)\end{array}$ & $\begin{array}{c}0.1315 \\
(0.3165)\end{array}$ \\
\hline
\end{tabular}


Table 6. Means of enhancing control and liquidity

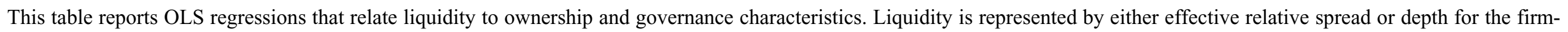

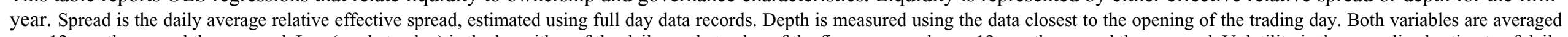

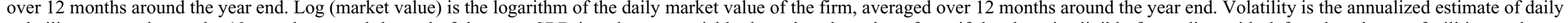

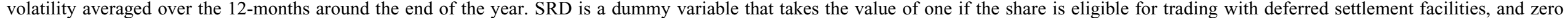

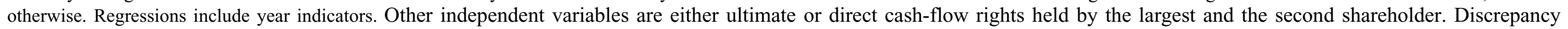

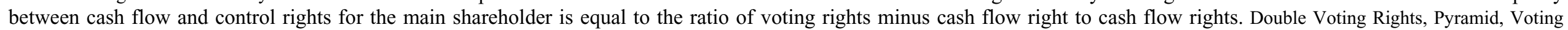
Caps, Dual Class Shares, Limited Partnership are dummies that equal 1 if the provision is present. $\mathrm{N}$ is the number of firm-year observations. $\mathrm{p}$-values are in parentheses.

\begin{tabular}{|c|c|c|c|c|c|c|c|c|}
\hline & \multicolumn{4}{|c|}{ Direct ownership impact } & \multicolumn{4}{|c|}{ Type of enhancing control device } \\
\hline Models & 1 & 2 & 3 & 4 & 5 & 6 & 7 & 8 \\
\hline variables & Spread & Spread & Depth & Depth & Spread & Spread & Spread & Depth \\
\hline Intercept & $\begin{array}{c}0.1076 \\
(<.0001)\end{array}$ & $\begin{array}{c}0.1088 \\
(<.0001)\end{array}$ & $\begin{array}{c}3.1051 \\
(<.0001)\end{array}$ & $\begin{array}{c}3.2565 \\
(<.0001)\end{array}$ & $\begin{array}{l}0.11048 \\
(<.0001)\end{array}$ & $\begin{array}{c}0.1133 \\
(<.0001)\end{array}$ & $\begin{array}{c}0.1152 \\
(<.0001)\end{array}$ & $\begin{array}{c}3.1639 \\
(<.0001)\end{array}$ \\
\hline \multicolumn{9}{|l|}{ Control variables } \\
\hline Log (market value) & $\begin{array}{c}-0.00551 \\
(<.0001)\end{array}$ & $\begin{array}{c}-0.00556 \\
(<.0001)\end{array}$ & $\begin{array}{c}0.3618 \\
(<.0001)\end{array}$ & $\begin{array}{c}0.3560 \\
(<.0001)\end{array}$ & $\begin{array}{l}-0.0055 \\
(<.0001)\end{array}$ & $\begin{array}{c}-0.00574 \\
(<.0001)\end{array}$ & $\begin{array}{c}-0.00567 \\
(<.0001)\end{array}$ & $\begin{array}{c}0.3532 \\
(<.0001)\end{array}$ \\
\hline Volatility & $\begin{array}{l}0.02960 \\
(<.0001)\end{array}$ & $\begin{array}{l}0.02973 \\
(<.0001)\end{array}$ & $\begin{array}{c}-0.2774 \\
(0.0070)\end{array}$ & $\begin{array}{l}-0.2656 \\
(0.0097)\end{array}$ & $\begin{array}{l}0.02982 \\
(<.0001)\end{array}$ & $\begin{array}{l}0.03000 \\
(<.0001)\end{array}$ & $\begin{array}{l}0.02915 \\
(<.0001)\end{array}$ & $\begin{array}{c}-0.2316 \\
(0.0248)\end{array}$ \\
\hline SRD & $\begin{array}{r}-0.00402 \\
(0.0011) \\
\end{array}$ & $\begin{array}{r}-0.00418 \\
(0.0007) \\
\end{array}$ & $\begin{array}{c}0.1474 \\
(0.0096) \\
\end{array}$ & $\begin{array}{l}0.13062 \\
(0.0226) \\
\end{array}$ & $\begin{array}{l}-0.0050 \\
(0.0003) \\
\end{array}$ & $\begin{array}{r}-0.00503 \\
(0.0007) \\
\end{array}$ & $\begin{array}{r}-0.00474 \\
(0.0001) \\
\end{array}$ & $\begin{array}{c}0.1690 \\
(0.0029) \\
\end{array}$ \\
\hline Year 2000 & $\begin{array}{c}0.00020 \\
0.8299\end{array}$ & $\begin{array}{l}0.00015 \\
(0.8719)\end{array}$ & $\begin{array}{c}-0.09679 \\
(0.0245)\end{array}$ & $\begin{array}{l}-0.1034 \\
(0.0160)\end{array}$ & $\begin{array}{c}0.00008 \\
0.9303\end{array}$ & $\begin{array}{c}0.00017 \\
0.8250\end{array}$ & $\begin{array}{c}0.00016 \\
0.8578\end{array}$ & $\begin{array}{c}-0.1024 \\
(0.0173)\end{array}$ \\
\hline Year 2002 & $\begin{array}{l}0.00516 \\
(<.0001)\end{array}$ & $\begin{array}{l}0.00507 \\
(<.0001)\end{array}$ & $\begin{array}{l}-0.2387 \\
(<.0001)\end{array}$ & $\begin{array}{l}-0.2496 \\
(<.0001)\end{array}$ & $\begin{array}{l}0.00505 \\
(<.0001)\end{array}$ & $\begin{array}{l}0.00506 \\
(<.0001)\end{array}$ & $\begin{array}{l}0.00515 \\
(<.0001)\end{array}$ & $\begin{array}{l}-0.2516 \\
(<.0001)\end{array}$ \\
\hline \multicolumn{9}{|l|}{ Direct ownership variables } \\
\hline Main shareholder & $\begin{array}{l}0.00016 \\
(<.0001) \\
\end{array}$ & $\begin{array}{l}0.00017 \\
(<.0001) \\
\end{array}$ & $\begin{array}{c}-0.00254 \\
(0.0005) \\
\end{array}$ & $\begin{array}{c}-0.00094 \\
(0.4333) \\
\end{array}$ & & $\begin{array}{l}0.00016 \\
(<.0001) \\
\end{array}$ & & \\
\hline Second shareholder & $\begin{array}{l}0.00017 \\
(0.0001) \\
\end{array}$ & $\begin{array}{l}0.00017 \\
(<.0001) \\
\end{array}$ & $\begin{array}{c}-0.00682 \\
(0.0006) \\
\end{array}$ & $\begin{array}{r}-0.00562 \\
(0.0141) \\
\end{array}$ & & & & \\
\hline $\begin{array}{l}\text { Discrepancy between cash flow } \\
\text { and control rights for the main } \\
\text { shareholder }\end{array}$ & $\begin{array}{c}-0.01266 \\
(<.0001)\end{array}$ & $\begin{array}{c}-0.01090 \\
(<.0001)\end{array}$ & $\begin{array}{c}-0.06904 \\
(0.5179)\end{array}$ & $\begin{array}{c}0.1498 \\
(0.2603)\end{array}$ & & & & \\
\hline \multicolumn{9}{|l|}{ Ultimate ownership variables } \\
\hline Main shareholder & & & & & $\begin{array}{l}0.00015 \\
(<.0001)\end{array}$ & & $\begin{array}{l}0.00020 \\
(<.0001)\end{array}$ & $\begin{array}{l}-0.0020 \\
(0.0063)\end{array}$ \\
\hline \multicolumn{9}{|l|}{ Governance dummies } \\
\hline Double voting rights & & & & & -0.00357 & -0.00366 & -0.00330 & -0.02843 \\
\hline
\end{tabular}




\begin{tabular}{|c|c|c|c|c|c|c|c|c|}
\hline & & & & & $(<.0001)$ & $(<.0001)$ & $(0.0001)$ & $(0.4568)$ \\
\hline Pyramid & & & & & $\begin{array}{l}0.00396 \\
(0.0001) \\
\end{array}$ & $\begin{array}{r}0.00228 \\
(0.0539) \\
\end{array}$ & $\begin{array}{l}0.00588 \\
(<.0001) \\
\end{array}$ & $\begin{array}{l}0.01946 \\
(0.6867) \\
\end{array}$ \\
\hline Voting cap & & & & & & $\begin{array}{c}0.001074 \\
(<.0001)\end{array}$ & & $\begin{array}{c}0.4210 \\
(0.0006)\end{array}$ \\
\hline Dual class & & & & & & $\begin{array}{c}0.00299 \\
(0.3658)\end{array}$ & & $\begin{array}{c}0.1633 \\
(0.3162)\end{array}$ \\
\hline Limited partnership & & & & & & $\begin{array}{l}-0.00157 \\
(0.5669)\end{array}$ & & $\begin{array}{c}0.1038 \\
(0.4321) \\
\end{array}$ \\
\hline \multicolumn{9}{|l|}{ Identity of controlling owner } \\
\hline Family control dummy & & $\begin{array}{c}-0.00155 \\
(0.1547) \\
\end{array}$ & & $\begin{array}{l}-0.2034 \\
(0.0432) \\
\end{array}$ & & & $\begin{array}{r}-0.00531 \\
(0.0011) \\
\end{array}$ & \\
\hline Non-family control dummy & & & & $\begin{array}{c}-0.02576 \\
(0.7954)\end{array}$ & & & $\begin{array}{r}-0.00696 \\
(0.0003)\end{array}$ & \\
\hline Number of observations & 1549 & 1549 & 1541 & 1541 & 1549 & 1549 & 1541 & 1541 \\
\hline Adjusted $\mathrm{R}^{2}$ & 0.6016 & 0.6018 & 0.6430 & 0.6455 & 0.5973 & 0.6008 & 0.6003 & 0.6428 \\
\hline
\end{tabular}


Table 7. Means of enhancing control and liquidity, for subsamples by control type

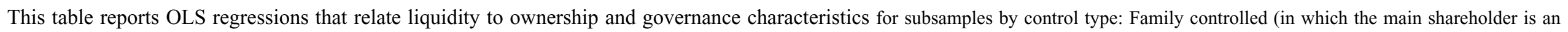

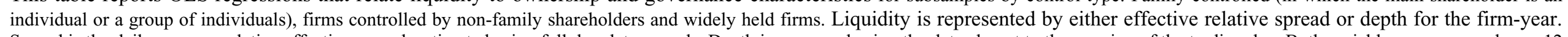

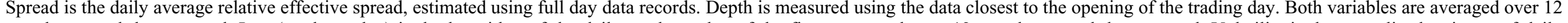

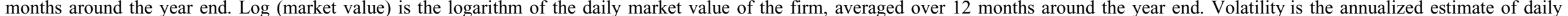

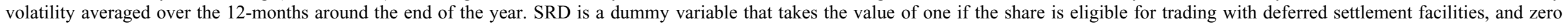

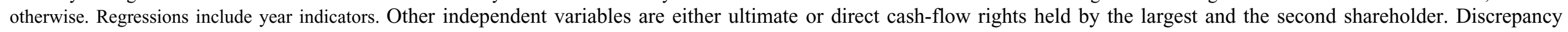

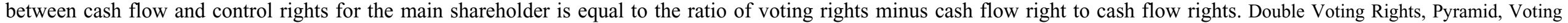
Caps, Dual Class Shares, Limited Partnership are dummies that equal 1 if the provision is present. $\mathrm{N}$ is the number of firm-year observations. p-values are in parentheses.

\begin{tabular}{|c|c|c|c|c|c|c|c|c|}
\hline \multirow[b]{2}{*}{ Models } & \multicolumn{2}{|c|}{ Widely held $(\mathrm{N}=203)$} & \multicolumn{3}{|c|}{ Family controlled $(\mathrm{N}=1086)$} & \multicolumn{3}{|c|}{ Non family controlled $(\mathrm{N}=261)$} \\
\hline & & & & & & & & \\
\hline variables & Spread & Depth & Spread & Spread & Depth & Spread & Spread & Depth \\
\hline Intercept & $\begin{array}{c}0.0978 \\
(<.0001)\end{array}$ & $\begin{array}{c}1.7237 \\
(<.0001)\end{array}$ & $\begin{array}{c}0.1223 \\
(<.0001)\end{array}$ & $\begin{array}{c}0.1352 \\
(<.0001)\end{array}$ & $\begin{array}{c}3.5740 \\
(<.0001)\end{array}$ & $\begin{array}{l}0.07604 \\
(<.0001)\end{array}$ & $\begin{array}{l}0.07399 \\
(<.0001)\end{array}$ & $\begin{array}{c}3.19 \\
(<.0001)\end{array}$ \\
\hline \multicolumn{9}{|l|}{ Control variables } \\
\hline Log (market value) & $\begin{array}{c}-0.00427 \\
(<.0001)\end{array}$ & $\begin{array}{c}0.4220 \\
(<.0001)\end{array}$ & $\begin{array}{l}-0.00687 \\
(<.0001)\end{array}$ & $\begin{array}{c}-0.00713 \\
(<.0001)\end{array}$ & $\begin{array}{c}0.3181 \\
(<.0001)\end{array}$ & $\begin{array}{c}-0.00402 \\
(<.0001)\end{array}$ & $\begin{array}{c}-0.00393 \\
(<.0001)\end{array}$ & $\begin{array}{c}0.3732 \\
(<.0001)\end{array}$ \\
\hline Volatility & $\begin{array}{l}0.01154 \\
(0.0102)\end{array}$ & $\begin{array}{r}-0.01431 \\
(0.9359) \\
\end{array}$ & $\begin{array}{l}0.02959 \\
(<.0001) \\
\end{array}$ & $\begin{array}{l}0.02878 \\
(<.0001)\end{array}$ & $\begin{array}{l}-0.2309 \\
(0.0496)\end{array}$ & $\begin{array}{l}0.04678 \\
(<.0001)\end{array}$ & $\begin{array}{l}0.04884 \\
(<.0001)\end{array}$ & $\begin{array}{c}-0.2298 \\
(0.4972) \\
\end{array}$ \\
\hline SRD & $\begin{array}{r}-0.00612 \\
(0.0146) \\
\end{array}$ & $\begin{array}{c}0.1886 \\
(0.0590) \\
\end{array}$ & $\begin{array}{r}-0.00094 \\
(0.5544) \\
\end{array}$ & $\begin{array}{r}-0.00232 \\
(0.1445)\end{array}$ & $\begin{array}{c}0.2326 \\
(0.0006)\end{array}$ & $\begin{array}{c}-0.01064 \\
(<.0001) \\
\end{array}$ & $\begin{array}{c}-0.01217 \\
(<.0001) \\
\end{array}$ & $\begin{array}{l}-0.1675 \\
(0.3034)\end{array}$ \\
\hline Year 2000 & $\begin{array}{c}-0.00315 \\
0.0937\end{array}$ & $\begin{array}{c}-0.2188 \\
(0.0038)\end{array}$ & $\begin{array}{l}0.00126 \\
(0.2639)\end{array}$ & $\begin{array}{c}0.00153 \\
0.1760\end{array}$ & $\begin{array}{c}-0.0902 \\
(0.0617)\end{array}$ & $\begin{array}{r}-0.00161 \\
(0.4441) \\
\end{array}$ & $\begin{array}{c}-0.00139 \\
0.5096\end{array}$ & $\begin{array}{c}-0.1168 \\
(0.4121)\end{array}$ \\
\hline Year 2002 & $\begin{array}{c}-0.00081 \\
(0.6770) \\
\end{array}$ & $\begin{array}{c}-0.2853 \\
(0.0003) \\
\end{array}$ & $\begin{array}{l}0.00718 \\
(<.0001) \\
\end{array}$ & $\begin{array}{l}0.00021 \\
(<.0001) \\
\end{array}$ & $\begin{array}{l}-0.2395 \\
(<.0001)\end{array}$ & $\begin{array}{c}-0.000745 \\
(<.0001) \\
\end{array}$ & $\begin{array}{c}-0.00052 \\
0.8178 \\
\end{array}$ & $\begin{array}{c}-0.3675 \\
(0.0165) \\
\end{array}$ \\
\hline Direct ownership variables & irrelevant & & & & & & & \\
\hline Main shareholder & & & $\begin{array}{c}0.0002759 \\
(<.0001)\end{array}$ & & & $\begin{array}{c}0.000146 \\
(0.0020) \\
\end{array}$ & & \\
\hline Second shareholder & & & $\begin{array}{l}0.000312 \\
(<.0001) \\
\end{array}$ & & & $\begin{array}{c}0.0000834 \\
(0.4134) \\
\end{array}$ & & \\
\hline $\begin{array}{l}\text { Discrepancy between cash flow } \\
\text { and control rights for the main } \\
\text { shareholder }\end{array}$ & & & $\begin{array}{l}-0.00595 \\
(0.0755)\end{array}$ & & & $\begin{array}{c}-0.00156 \\
(0.8176)\end{array}$ & & \\
\hline Ultimate ownership variables & irrelevant & & & & & & & \\
\hline Main shareholder & & & & $\begin{array}{l}0.00021 \\
(<.0001)\end{array}$ & $\begin{array}{l}0.00019 \\
(0.8601)\end{array}$ & & $\begin{array}{l}0.00012 \\
(0.0016)\end{array}$ & $\begin{array}{l}-0.00418 \\
(0.1055)\end{array}$ \\
\hline
\end{tabular}




\begin{tabular}{|l|c|c|c|c|c|c|c|c|}
\hline Governance dummies & & & & & & & \\
\hline Double voting rights & 0.00058 & 0.0606 & & -0.00501 & 0.05332 & & -0.00132 & -0.1224 \\
& $(0.6986)$ & $(0.3098)$ & & $(<.0001)$ & $(0.2622)$ & & 0.4595 & $(0.3035)$ \\
\hline Pyramid & & & & 0.00417 & 0.0777 & & 0.00395 & 0.0099 \\
& & & & $(0.0050)$ & $(0.2436)$ & & $(0.0030)$ & $(0.9351)$ \\
\hline Voting cap & 0.00760 & 0.4467 & & 0.00278 & -0.1096 & & -0.00242 & -0.07195 \\
& $(0.0055)$ & $(<.0001)$ & & $(0.6095)$ & $(0.6354)$ & & $(0.7008)$ & $(0.8640)$ \\
\hline Dual class & 0.00739 & -0.1476 & & 0.00539 & 0.2698 & & & \\
& $(0.4816)$ & $(0.7250)$ & & $(0.1406)$ & $(0.0912)$ & & & \\
\hline Limited partnership & 0.000739 & 0.03806 & & -0.00177 & -0.1766 & & 0.00351 & 1.0064 \\
& $(0.7985)$ & $(0.7420)$ & & $(0.7273)$ & $(0.4139)$ & & $(0.6188)$ & $(0.0331)$ \\
\hline Adjusted R ${ }^{2}$ & 0.6659 & 0.9110 & 0.5943 & 0.5915 & 0.5572 & 0.6226 & 0.6274 & 0.4374 \\
\hline
\end{tabular}


Table 8. Regressions for subsamples by means of control enhancement

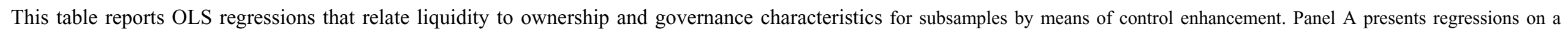

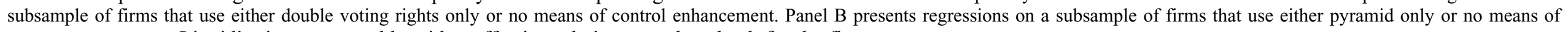

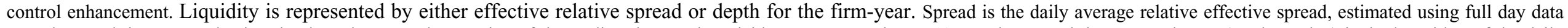

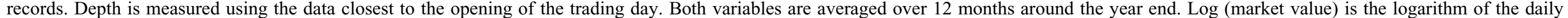

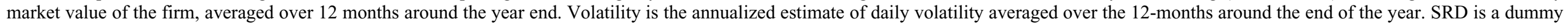

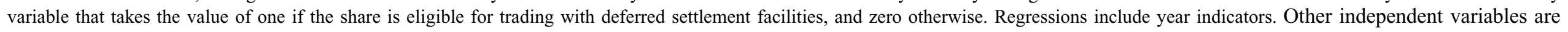

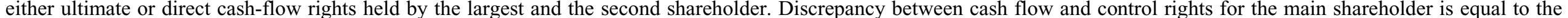

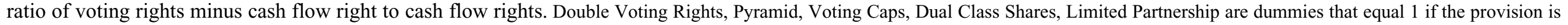
present. $\mathrm{N}$ is the number of firm-year observations. p-values are in parentheses.

\begin{tabular}{|c|c|c|c|c|c|c|}
\hline \multicolumn{7}{|c|}{ Panel A. Firms using double voting rights only and firms using no control enhancing device } \\
\hline & \multicolumn{2}{|c|}{ Widely held $(\mathrm{N}=89)$} & \multicolumn{2}{|c|}{ Family controlled $(\mathrm{N}=561)$} & \multicolumn{2}{|c|}{ Non family controlled $(\mathrm{N}=63)$} \\
\hline Models & 1 & 2 & 3 & 4 & 5 & 6 \\
\hline Dependent variables & Spread & Depth & Spread & Depth & Spread & Depth \\
\hline \multicolumn{7}{|l|}{ Independent variables } \\
\hline Intercept & $\begin{array}{c}0.1066 \\
(<0.0001)\end{array}$ & $\begin{array}{c}1.9500 \\
(0.0004)\end{array}$ & $\begin{array}{c}0.1406 \\
(<0.0001)\end{array}$ & $\begin{array}{c}3.2379 \\
(<0.0001)\end{array}$ & $\begin{array}{c}0.0610 \\
(0.0081)\end{array}$ & $\begin{array}{c}5.9243 \\
(<0.0001)\end{array}$ \\
\hline \multicolumn{7}{|l|}{ Control variables } \\
\hline Log (market value) & $\begin{array}{l}-0.00493 \\
(<0.0001)\end{array}$ & $\begin{array}{c}0.4042 \\
(<0.0001)\end{array}$ & $\begin{array}{c}-0.00744 \\
(<0.0001)\end{array}$ & $\begin{array}{c}0.3288 \\
(<0.0001)\end{array}$ & $\begin{array}{c}-0.00302 \\
(0.00108)\end{array}$ & $\begin{array}{c}0.2332 \\
(0.0019)\end{array}$ \\
\hline Volatility & $\begin{array}{l}0.01759 \\
(0.0256)\end{array}$ & $\begin{array}{c}0.2276 \\
(0.3747)\end{array}$ & $\begin{array}{c}0.02389 \\
(<0.0001)\end{array}$ & $\begin{array}{l}-0.02983 \\
(0.8446)\end{array}$ & $\begin{array}{c}0.04112 \\
(<0.0001)\end{array}$ & $\begin{array}{c}-0.5402 \\
(0.2947)\end{array}$ \\
\hline SRD & $\begin{array}{r}-0.00444 \\
(0.2063) \\
\end{array}$ & $\begin{array}{c}0.2093 \\
(0.0723) \\
\end{array}$ & $\begin{array}{l}-0.00014 \\
(0.9549) \\
\end{array}$ & $\begin{array}{c}0.1511 \\
(0.1112) \\
\end{array}$ & $\begin{array}{l}-0.01369 \\
(0.0141) \\
\end{array}$ & $\begin{array}{c}0.2031 \\
(0.5496) \\
\end{array}$ \\
\hline Year 2000 & $\begin{array}{r}-0.00506 \\
(0.0949) \\
\end{array}$ & $\begin{array}{c}-0.2912 \\
(0.0041) \\
\end{array}$ & $\begin{array}{l}0.00126 \\
(0.4110) \\
\end{array}$ & $\begin{array}{c}-0.0978 \\
(0.0962) \\
\end{array}$ & $\begin{array}{l}-0.00210 \\
(0.6047)\end{array}$ & $\begin{array}{c}-0.1764 \\
(0.4882) \\
\end{array}$ \\
\hline Year 2002 & $\begin{array}{r}-0.00433 \\
(0.2150)\end{array}$ & $\begin{array}{c}-0.4156 \\
(0.0005)\end{array}$ & $\begin{array}{c}0.00758 \\
(<0.0001)\end{array}$ & $\begin{array}{c}-0.1297 \\
(0.0658)\end{array}$ & $\begin{array}{r}-0.000379 \\
(0.9331))\end{array}$ & $\begin{array}{c}-0.2148 \\
(0.4487)\end{array}$ \\
\hline \multicolumn{7}{|c|}{ Direct ownership variables } \\
\hline Main shareholder & irrelevant & irrelevant & $\begin{array}{c}0.00028 \\
(<0.0001)\end{array}$ & $\begin{array}{c}0.000476 \\
(0.7304)\end{array}$ & $\begin{array}{c}0.000099 \\
(0.2240)\end{array}$ & $\begin{array}{c}-0.0060 \\
(0.2406)\end{array}$ \\
\hline \multicolumn{7}{|l|}{ Governance dummies } \\
\hline Double voting rights & $\begin{array}{l}0.00097 \\
(0.6860) \\
\end{array}$ & $\begin{array}{l}0.00955 \\
(0.9039) \\
\end{array}$ & $\begin{array}{c}-0.00683 \\
(<0.0001)\end{array}$ & $\begin{array}{c}0.0685 \\
(0.2374) \\
\end{array}$ & $\begin{array}{c}0.00016 \\
(0.9644)) \\
\end{array}$ & $\begin{array}{c}-0.0795 \\
(0.7194) \\
\end{array}$ \\
\hline Adjusted $\mathrm{R}^{2}$ & 0.6471 & 0.8953 & 0.5597 & 0.5209 & 0.5883 & 0.3507 \\
\hline
\end{tabular}




\begin{tabular}{|l|c|c|c|c|}
\hline \multicolumn{5}{|c|}{ Panel B. Firms using pyramids only and firms using no control enhancing device } \\
\hline & \multicolumn{2}{|c|}{ Family controlled $(\mathrm{N}=202)$} & \multicolumn{2}{c|}{ Non family controlled (N=107) } \\
\hline Models & 1 & 2 & 3 & 4 \\
\hline Dependent variables & Spread & Depth & Spread & Depth \\
\hline Independent variables & & & & \\
\hline Intercept & 0.12298 & 3.4514 & 0.08306 & 3.1347 \\
& $(<0.0001)$ & $(<0.0001)$ & $(<0.0001)$ & $(0.0085)$ \\
\hline Control variables & & & & \\
\hline Log (market value) & -0.00686 & 0.3321 & -0.00503 & 0.3730 \\
& $(<0.0001)$ & $(<0.0001)$ & $(<0.0001)$ & $(<0.0001)$ \\
\hline Volatility & 0.01804 & 0.08844 & 0.06596 & -0.7216 \\
& $(0.0213)$ & $(0.7220)$ & $(<0.0001)$ & $(0.1543)$ \\
\hline SRD & -0.00467 & 0.2097 & -0.01178 & -0.2591 \\
& $(0.4368)$ & $(0.2745)$ & $(0.0075)$ & $(0.3491)$ \\
\hline Year 2000 & 0.00511 & -0.0847 & -0.00252 & 0.0688 \\
& $(0.1281)$ & $(0.4294)$ & $(0.4524)$ & $(0.7501)$ \\
\hline Year 2002 & 0.01465 & -0.1874 & 0.00246 & -0.4671 \\
& $(0.0003)$ & $(0.1462)$ & $(0.5483)$ & $(0.0762)$ \\
\hline & & & & \\
\hline Direct ownership variables & & & & \\
\hline Main shareholder & 0.0004095 & -0.0051 & 0.0001770 & -0.00036 \\
& $(<0.0001)$ & $(0.0387)$ & $(0.0101)$ & $(0.9338)$ \\
\hline & & & & \\
\hline Governance dummies & & & & 0.1216 \\
\hline Pyramid & & 0.1843 & 0.00648 & $(0.5427)$ \\
\hline & 0.00179 & $(0.1403)$ & $(0.0378)$ & \\
\hline Adjusted R ${ }^{2}$ & & & & 0.4210 \\
\hline
\end{tabular}


Table 9. Adverse selection component of spread

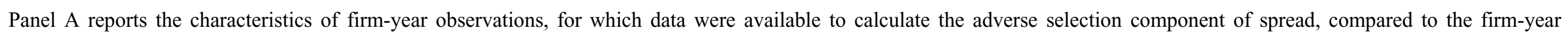

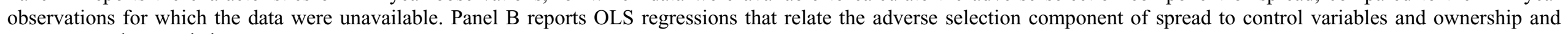

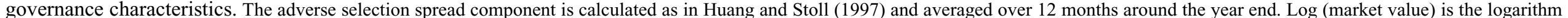

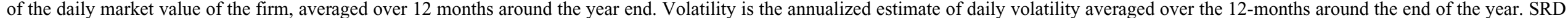

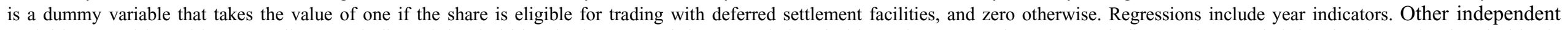

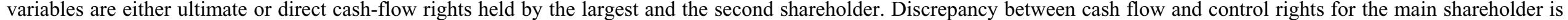

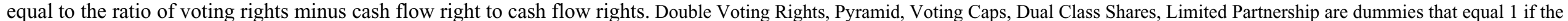
provision is present. $\mathrm{N}$ is the number of firm-year observations. p-values are in parentheses.

\begin{tabular}{|c|c|c|c|c|c|}
\hline \multicolumn{6}{|c|}{ Panel A. Characteristics of the firms for which the adverse component of spread can be calculated compared to other firms } \\
\hline & \multicolumn{2}{|c|}{$\begin{array}{l}\text { Adverse component of } \\
\text { spread available }\end{array}$} & \multicolumn{3}{|c|}{ Adverse component of spread unavailable } \\
\hline Number of observations (\% of total) & 1087 & $70.13 \%$ & \multicolumn{2}{|c|}{463} & $29.87 \%$ \\
\hline Number of family-firms & 697 & $64.18 \%$ & \multicolumn{2}{|c|}{389} & $35.82 \%$ \\
\hline Number of other-controlled firms & 202 & $77.39 \%$ & \multicolumn{2}{|c|}{59} & $22.61 \%$ \\
\hline Number of widely-held firms & 188 & $92.61 \%$ & \multicolumn{2}{|c|}{15} & $7.39 \%$ \\
\hline & Mean & Median & Mean & Median & $\begin{array}{l}\text { p-values from Student test } \\
\text { (median test) }\end{array}$ \\
\hline Market capitalization ( $€$ million $)$ & 2,878 & 254 & 97 & 25 & $<0.0001(<0.0001)$ \\
\hline Turnover (daily average in $000 €$ ) & 9,227 & 205 & 16.4 & 7.8 & $\begin{array}{l}<0.0001 \\
(<0.0001)\end{array}$ \\
\hline Float ( $20 \%$ Threshold), in $\%$ of capital & 56.21 & 50.04 & 39.20 & 37.48 & $\begin{array}{l}<0.0001 \\
(<0.0001)\end{array}$ \\
\hline Ultimate $\%$ capital of the main shareholder & 38.87 & 41.50 & 54.87 & 56.54 & $\begin{array}{l}<0.0001 \\
(<0.0001)\end{array}$ \\
\hline Ultimate $\%$ of voting rights of the main shareholder & 46.52 & 52.80 & 61.52 & 64.25 & $\begin{array}{l}<0.0001 \\
(<0.0001)\end{array}$ \\
\hline Ultimate $\%$ capital of the second shareholder & 7.15 & 5.44 & 7.76 & 5.07 & $\begin{array}{c}0.2178 \\
(0.3489)\end{array}$ \\
\hline Ultimate \% voting rights of the second shareholder & 7.81 & 6.20 & 8.22 & 6.00 & $\begin{array}{c}0.4384 \\
(0.4229)\end{array}$ \\
\hline $\begin{array}{l}\text { Discrepancy between ultimate cash flow and control rights for the } \\
\text { main shareholder }\end{array}$ & 0.3136 & 0.1948 & 0.1785 & 0.07652 & $\begin{array}{l}<0.0001 \\
(<0.0001)\end{array}$ \\
\hline Average relative effective spread - full day's data records, in \% & $1.73 \%$ & $1.41 \%$ & $4.70 \%$ & $3.93 \%$ & $\begin{array}{l}<0.0001 \\
(<0.0001)\end{array}$ \\
\hline Depth (daily average at opening in $000 €$ ) & 41.55 & 14.34 & 24.95 & 6.96 & $\begin{array}{c}0.0038 \\
(<0.0001)\end{array}$ \\
\hline Adverse selection component of spread (in \% of total spread) & 0.07736 & 0.05409 & na & na & \\
\hline
\end{tabular}




\begin{tabular}{|c|c|c|c|c|c|c|c|c|c|c|c|c|}
\hline \multicolumn{13}{|c|}{ Panel B. Adverse selection component of the spread and ownership characteristics } \\
\hline & \multicolumn{6}{|c|}{ Total sample } & \multicolumn{3}{|c|}{ Family-controlled firms } & \multicolumn{3}{|c|}{ Non-family controlled firms } \\
\hline Models & 1 & 2 & 3 & 4 & 5 & & 6 & 7 & 8 & 9 & 10 & 11 \\
\hline Intercept & $\begin{array}{c}0.2623 \\
(<0.0001)\end{array}$ & $\begin{array}{c}0.3010 \\
(<0.0001)\end{array}$ & $\begin{array}{c}0.1863 \\
(<0.0001)\end{array}$ & $\begin{array}{c}0.1994 \\
(<0.0001)\end{array}$ & $\begin{array}{c}0.2088 \\
(<0.0001)\end{array}$ & $\begin{array}{c}0.2153 \\
(<0.0001)\end{array}$ & $\begin{array}{c}0.1973 \\
(<0.0001)\end{array}$ & $\begin{array}{c}0.1991 \\
(<0.0001)\end{array}$ & $\begin{array}{c}0.2201 \\
(<0.0001)\end{array}$ & $\begin{array}{c}0.1961 \\
(0.0005) \\
\end{array}$ & $\begin{array}{c}0.2063 \\
(0.0004) \\
\end{array}$ & $\begin{array}{c}0.2320 \\
(0.0001) \\
\end{array}$ \\
\hline \multicolumn{13}{|l|}{ Control variables } \\
\hline Log (market value) & $\begin{array}{c}-0.00821 \\
(<0.0001)\end{array}$ & $\begin{array}{c}-0.00879 \\
(<0.0001)\end{array}$ & $\begin{array}{c}-0.00767 \\
(<0.0001) \\
\end{array}$ & $\begin{array}{c}-0.00811 \\
(<0.0001)\end{array}$ & $\begin{array}{c}-0.00830 \\
(<0.0001)\end{array}$ & $\begin{array}{c}-0.00846 \\
(<0.0001)\end{array}$ & $\begin{array}{c}-0.01045 \\
(<0.0001)\end{array}$ & $\begin{array}{c}-0.01069 \\
(<0.0001)\end{array}$ & $\begin{array}{c}-0.01055 \\
(<0.0001)\end{array}$ & $\begin{array}{c}-0.00898 \\
(0.001) \\
\end{array}$ & $\begin{array}{l}-0.00890 \\
(0.0018) \\
\end{array}$ & $\begin{array}{l}-0.00856 \\
(0.0030) \\
\end{array}$ \\
\hline Volatility & $\begin{array}{l}-0.00216 \\
(0.8679) \\
\end{array}$ & $\begin{array}{c}-0.00656 \\
(0.6164) \\
\end{array}$ & $\begin{array}{l}0.00237 \\
(0.8574)\end{array}$ & $\begin{array}{l}-0.00325 \\
(0.8037) \\
\end{array}$ & $\begin{array}{c}-0.00340 \\
(0.7989) \\
\end{array}$ & $\begin{array}{l}-0.00526 \\
(0.6955) \\
\end{array}$ & $\begin{array}{c}-0.000209 \\
(0.9909)\end{array}$ & $\begin{array}{c}-0.000364 \\
(0.9843)\end{array}$ & $\begin{array}{c}0.0074 \\
(0.6954) \\
\end{array}$ & $\begin{array}{c}0.0155 \\
(0.5586) \\
\end{array}$ & $\begin{array}{r}-0.01244 \\
(0.6391) \\
\end{array}$ & $\begin{array}{r}-0.01337 \\
(0.6347) \\
\end{array}$ \\
\hline SRD & $\begin{array}{c}-0.03564 \\
(<0.0001)\end{array}$ & $\begin{array}{c}-0.03366 \\
(<0.0001)\end{array}$ & $\begin{array}{c}-0.03598 \\
(<0.0001)\end{array}$ & $\begin{array}{c}-0.03489 \\
(<0.0001)\end{array}$ & $\begin{array}{c}-0.03845 \\
(<0.0001)\end{array}$ & $\begin{array}{c}-0.03734 \\
(<0.0001)\end{array}$ & $\begin{array}{c}-0.02722 \\
(0.0013) \\
\end{array}$ & $\begin{array}{l}-0.02729 \\
(0.0011) \\
\end{array}$ & $\begin{array}{c}-0.03465 \\
(<0.0001)\end{array}$ & $\begin{array}{l}-0.03930 \\
(0.0006) \\
\end{array}$ & $\begin{array}{l}-0.03811 \\
(0.0011) \\
\end{array}$ & $\begin{array}{l}-0.04580 \\
(0.0001) \\
\end{array}$ \\
\hline Year 2000 & $\begin{array}{l}0.00708 \\
(0.1733)\end{array}$ & $\begin{array}{l}0.00744 \\
(0.1517)\end{array}$ & $\begin{array}{l}0.00604 \\
(0.2464)\end{array}$ & $\begin{array}{l}0.00645 \\
(0.2152)\end{array}$ & $\begin{array}{l}0.00715 \\
(0.1735)\end{array}$ & $\begin{array}{l}0.00751 \\
(0.1533)\end{array}$ & $\begin{array}{l}0.00576 \\
(0.4124)\end{array}$ & $\begin{array}{l}0.00544 \\
(0.4373)\end{array}$ & $\begin{array}{l}0.00732 \\
(0.3014)\end{array}$ & $\begin{array}{c}0.0115 \\
(0.2698)\end{array}$ & $\begin{array}{c}0.01283 \\
(0.2331)\end{array}$ & $\begin{array}{l}0.01438 \\
(0.1967)\end{array}$ \\
\hline Year 2002 & $\begin{array}{c}0.06772 \\
(<0.0001)\end{array}$ & $\begin{array}{c}0.06831 \\
(<0.0001)\end{array}$ & $\begin{array}{c}0.05659 \\
(<0.0001)\end{array}$ & $\begin{array}{c}0.06712 \\
(<0.0001)\end{array}$ & $\begin{array}{c}0.06727 \\
(<0.0001)\end{array}$ & $\begin{array}{c}0.06783 \\
(<0.0001)\end{array}$ & $\begin{array}{c}0.07184 \\
(<0.0001)\end{array}$ & $\begin{array}{c}0.07249 \\
(<0.0001)\end{array}$ & $\begin{array}{c}0.07389 \\
(<0.0001)\end{array}$ & $\begin{array}{c}0.05611 \\
(<0.0001)\end{array}$ & $\begin{array}{c}0.05960 \\
(<0.0001)\end{array}$ & $\begin{array}{c}0.06065 \\
(<0.0001)\end{array}$ \\
\hline Free Float (at the $20 \%$ threshold) & $\begin{array}{c}-0.06046 \\
(<0.0001) \\
\end{array}$ & $\begin{array}{c}-0.07995 \\
(<0.0001)\end{array}$ & & & & & & & & & & \\
\hline \multicolumn{13}{|l|}{ Ultimate ownership variables } \\
\hline Main shareholder & & & $\begin{array}{l}0.0005987 \\
(<0.0001) \\
\end{array}$ & & $\begin{array}{l}0.0005178 \\
(<0.0001)\end{array}$ & $\begin{array}{l}0.0006169 \\
(<0.0001) \\
\end{array}$ & $\begin{array}{c}0.00120 \\
(<0.0001)\end{array}$ & & $\begin{array}{c}0.000817 \\
(<0.0001)\end{array}$ & $\begin{array}{c}0.0007888 \\
(0.0006) \\
\end{array}$ & & $\begin{array}{c}0.0002874 \\
(0.1554) \\
\end{array}$ \\
\hline Second shareholder & & & $\begin{array}{c}0.0006941 \\
(0.0051)\end{array}$ & & & & $\begin{array}{c}0.00150 \\
(<0.0001)\end{array}$ & & & $\begin{array}{c}0.0003678 \\
(0.4347)\end{array}$ & & \\
\hline $\begin{array}{l}\text { Discrepancy between cash flow and } \\
\text { control rights for the main } \\
\text { shareholder }\end{array}$ & & & $\begin{array}{l}0.01335 \\
(0.0005)\end{array}$ & & & & $\begin{array}{l}0.02436 \\
(0.0020)\end{array}$ & & & $\begin{array}{c}0.02295 \\
(<0.0001)\end{array}$ & & \\
\hline \multicolumn{13}{|l|}{ Direct ownership variables } \\
\hline Main shareholder & & & & $\begin{array}{l}0.0005758 \\
(<0.0001) \\
\end{array}$ & & & & $\begin{array}{c}0.00121 \\
(<0.0001)\end{array}$ & & & $\begin{array}{c}0.0007124 \\
(0.0027) \\
\end{array}$ & \\
\hline Second shareholder & & & & $\begin{array}{l}0.0009334 \\
(<0.0001)\end{array}$ & & & & $\begin{array}{c}0.00171 \\
(<0.0001)\end{array}$ & & & $\begin{array}{c}0.0009757 \\
(0.0477)\end{array}$ & \\
\hline $\begin{array}{l}\text { Discrepancy between cash flow } \\
\text { and control rights for the main } \\
\text { shareholder }\end{array}$ & & & & $\begin{array}{c}-0.01421 \\
(0.2350)\end{array}$ & & & & $\begin{array}{l}0.01824 \\
(0.3306)\end{array}$ & & & $\begin{array}{l}0.00602 \\
(0.8513)\end{array}$ & \\
\hline \multicolumn{13}{|l|}{ Governance dummies } \\
\hline Double voting rights & & & & & $\begin{array}{c}0.00101 \\
(0.8289) \\
\end{array}$ & $\begin{array}{c}0.0003960 \\
(0.9363)\end{array}$ & & & $\begin{array}{l}0.00843 \\
(0.2538) \\
\end{array}$ & & & $\begin{array}{l}0.00223 \\
(0.8021) \\
\end{array}$ \\
\hline Pyramid & & & & & $\begin{array}{r}0.01033 \\
(0.0623) \\
\end{array}$ & $\begin{array}{l}0.01507 \\
(0.0181) \\
\end{array}$ & & & $\begin{array}{r}0.02888 \\
(0.0014) \\
\end{array}$ & & & $\begin{array}{l}0.00501 \\
(0.6031) \\
\end{array}$ \\
\hline Voting cap & & & & & $\begin{array}{r}0.00980 \\
(0.4236) \\
\end{array}$ & $\begin{array}{c}0.0087 \\
(0.4800) \\
\end{array}$ & & & $\begin{array}{r}0.03686 \\
(0.1589) \\
\end{array}$ & & & $\begin{array}{r}-0.01562 \\
(0.5842) \\
\end{array}$ \\
\hline
\end{tabular}




\begin{tabular}{|c|c|c|c|c|c|c|c|c|c|c|c|c|}
\hline Dual class & & & & & $\begin{array}{c}- \\
0.0007667 \\
(0.9623)\end{array}$ & $\begin{array}{l}-0.00117 \\
(0.9427)\end{array}$ & & & $\begin{array}{c}0.000873 \\
(0.9616)\end{array}$ & & & na \\
\hline Limited partnership & & & & & $\begin{array}{c}-0.00342 \\
(0.8018)\end{array}$ & $\begin{array}{c}-0.00326 \\
(0.8112)\end{array}$ & & & $\begin{array}{l}-0.00451 \\
(0.8536)\end{array}$ & & & $\begin{array}{c}-0.02550 \\
(0.4260)\end{array}$ \\
\hline \multicolumn{13}{|l|}{ Identity of controlling owner } \\
\hline Family control dummy & & $\begin{array}{r}-0.01776 \\
(0.0301)\end{array}$ & & & & $\begin{array}{c}-0.00732 \\
(0.3912)\end{array}$ & & & & & & \\
\hline Non-family control dummy & & $\begin{array}{l}-0.02150 \\
(0.0203)\end{array}$ & & & & $\begin{array}{c}-0.01477 \\
(0.1505)\end{array}$ & & & & & & \\
\hline Number of observations & 1087 & 1087 & 1087 & 1087 & 1087 & 1087 & 697 & 697 & 697 & 202 & 202 & 202 \\
\hline Adjusted $\mathrm{R}^{2}$ & 0.3652 & 0.3674 & 0.3646 & 0.3652 & 0.3518 & 0.3519 & 0.3397 & 0.3454 & 0.3270 & 0.4054 & 0.3653 & 0.3356 \\
\hline
\end{tabular}


${ }^{1}$ See for example Dennis and Weston (2001) and Sarin, Shastri and Shastri. (2000).

${ }^{2}$ La Porta et al. (2002) find a positive relation between investor protection and Tobin's Q. Claessens et al. (2002) show for a sample of Asian firms that the difference between control rights and cash flow rights is associated with a value discount. Further, the discount increases with the size of the wedge between control rights and cash flow rights. They find that family controlled firms drive their results. Bebchuk, Kraakman, and Triantis (2000) argue that separating control rights from cash-flow rights can create agency costs larger than the costs associated with a controlling shareholder who also has a majority of the cash-flow rights in his company.

${ }^{3}$ Private benefits include for instance CEO appointment, perquisites enjoyed by top executives and deviations from fair transfer prices of products or assets.

${ }^{4}$ Before September 20, 1999, trading was carried out from 10.00 to 17.00 , then until the April 3, 2000 from 9.00 to 17.00 . After that date, the closing call auction has been postponed to 17.35. Since April 23, 2001, the current schedules are in force.

5 To calculate the voting rights, we did not take into account the voting caps, as their limiting impact may depend on the number of shareholders attending the general meeting.

${ }^{6}$ All the tests have also been conducted with quoted spreads. The results are similar, and thus are not reported in the paper.

${ }^{7}$ The level of share prices in Europe is very heterogeneous across stocks, so that spreads in Euros are not comparable among firms. Therefore we have chosen to present the results with relative spreads.

${ }^{8}$ For a review of the determinants of bid-ask spreads, see Bollen, Smith and Whaley (2003). For a review of the market microstructure literature, see Stoll (2003).

${ }^{9}$ For example, on February 10, 1999 at $11 \mathrm{~h} 36^{\text {' }} 23$ ', a buying order of shares Renault (included in the Cac40 index) is executed on 84 limits of price in the order book. The 84 execution prices lie between 43.79 and $47.50 €$ for a total quantity of 86,743 and an execution value weighted average price of $45.46 €$. There were 336 counterparts in the execution of the order. The preceding execution price was $43.64 €$, the bid and ask prices were respectively 43.64 and 43.79 . The quoted spread and the effective spread were both equal to $0.15 €$. This equality between quoted and effective spreads is very common in Paris. Even the majority of the crossing trades are executed either at the ask or the bid price. Just after the transaction, the best limits are quoted at 43.64/47.50 and the effective and quoted spreads are of $3.86 €(8.47 \%$ of the mid-quote spread). The transaction leaves the bid 
unchanged and moves the ask, with an increase of $3.61 \%$ in the mid-quote. In this example the price change compared to the last transaction is fixed at $47.5-43.64=3.86 €$, by retaining the marginal price of execution of the large size transaction (and not a value weighted average price). 